\title{
دور العتبتين المسينية والعباسية المقدستين في النشر الأكاديمي
}

\author{
م. د. ثامر مكي علي الشمري/ كلية الآداب / الجامعة المستنـصرية

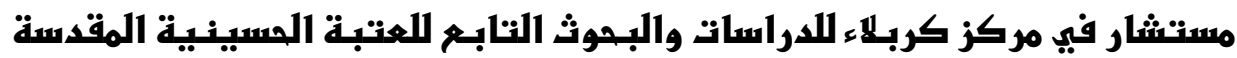

الاقدمية

تعد الصحافة صورة من صور الحضارة في اي بلد، بل إنها " ركن من أعظم الأركان التي تثيد عليها

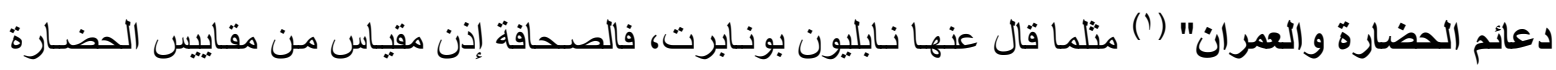

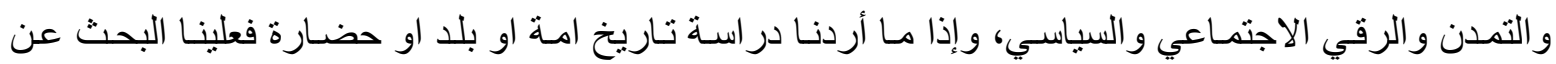
صحافتها وتفاعلها مـع المجتمع وقدرتها على التأثز بحركته والتأثير فيه، ومن هنـا تكمن أهمية البحث عن تاريخ الصحافة في كربلاء بشكل عام، وصحافة العتبات المقسة في كربلاء بشكل خاص. كما شهدت محافظة

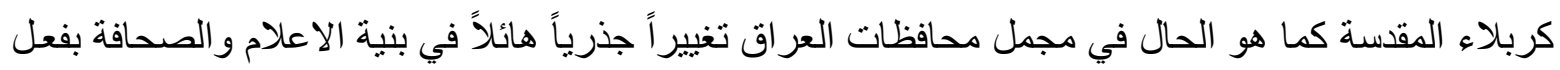
الفورة الهائلة التي شهدها المجتمع العر اقي على مختلف الأصعدة ومنها الصعيد الصحفي و الإعلامسي على اثر هري عملية التحرر و الانفتاح وشيوع الحريات بأوسع أبو ابها بعد انهيار سلطة حزب البعث الحاكم في عام ب . . ب. كما شهرد المجال الصحفي في كربلاء بشكل عـام، و العتبـات المقدسة بشكل خـاص نقلة نوعيـة تمثلت بصدور عشرات الجر ائد ومثلها بل و اكثر من المجلات والنشرات بمختلف اصنافها وطروحاتها وتر افق ذلك مع بروز جيل جديد من الثباب الصحفي المتحرر، لدرجة يمكن معها اعتبار فترة الـــا با عام الماضية فترة

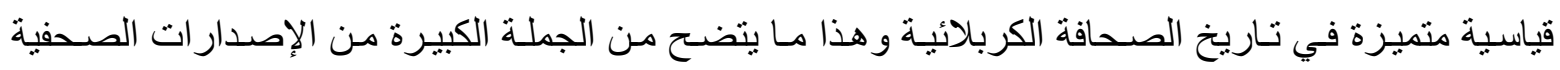

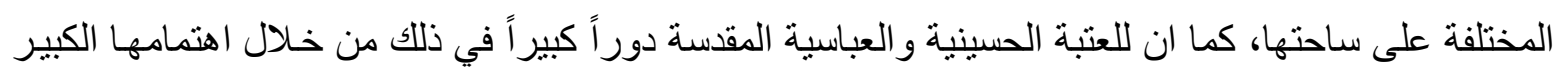
بالمجال الصحفي، اذ انشئت بين جدر انها وخارجـه الكثير من الثـب و الاقسـام التي تهنت بـالأعلام والثـؤون الفكرية و التقافية، فانبيقت من هذه الامـاكن العديد من المجلات المحكمـة و غير المحكمـة و الجر ائد و النشـرات

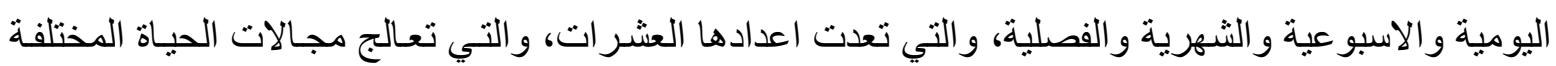
السياسية منها والاجتماعية والاقتصادية، والتي سنبين الجزء الاكبر منها قدر الامكان في هذا البحث. و انسجاما مع عمل الباحث الأكاديمي في الجامعة المستتصرية، و ادارته لمجلة السبط المحكمة في مركز كربلاء للار اسـات والبحوث في العتبـة الحسينة المقدسة، وشـعار المؤتمر (حركة النشـر وتطوير الدراسـات الانسانية) ومحاوره، وقع الاختيار على (دور العتبتين الحسينية والعباسية المقدستين في النشر الأكاديمي) كعنوان للمشاركة، وجاء ليجيب على العديد من الأسئلة والتي تمثل فرضيته واشكاليته، منها: ا ـ لماذا تهتم العتبتين المقدستين بنشر البحوث الاكاديمية؟. r- هل تؤدي دوراً في عملية نشر البحوث الاكاديمية؟ وكيف؟ r- هل يواجه الباحثين اية صعوبات عند النشر في المجلات المحكمة للعتبتين المقدستين؟ نتيجة لذلك قُسم البحث الى ثناث مباحث، تتـاول المبحث الأول: نبذة مختصرة عن صحافة العتبتين

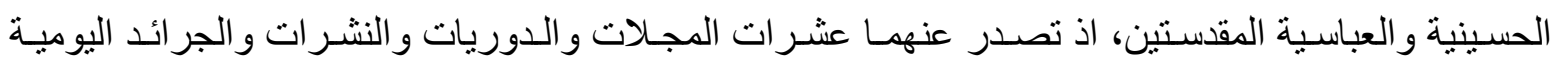


و الأسبو عية والثـهرية و الفصلية والسنوية وفي المناسبات الدينية، بينمـا درس المبحث الثاني: دور مجلات

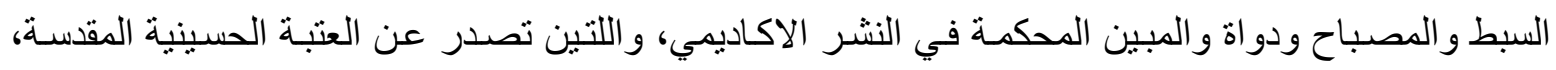
وخصص المبحث الثالث لدراسة دور مجلات العميد وتراث كربلاء و الباهر وتر اث الحلة وتسليم، المحكمة ونة في نشر الأبحاث الاكاديمية لأساتذة الجامعات، اذ تصدر هاتين المجلتين من قبل العتبة العباسية المقدة. امـا اهـم المصـادر التـي اسـتقى البحـث معلوماتـهـه منهـا فكانـت الاعـداد الأولى مـن مجـلات العتبتين المقدستين، اذ احتوت هذه الاعداد على معلومـات مهمـة، لاسيما في جانب تغطية تـاريخ صدور ها وهيأتها

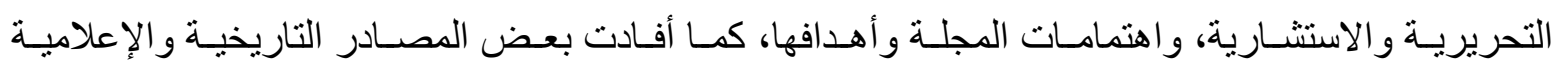
و الصحف بعض أجز اء من البحث، فضلاً عن ان الباحث استفاد كثيراً من المقابلات الثخصية التي اجر اها ميع المشـرفين العـامين عليها ورؤسـاء ومدر اء تحرير هـا، و العمل الميداني الذي قام بـه الباحث من خـلال زيـارة

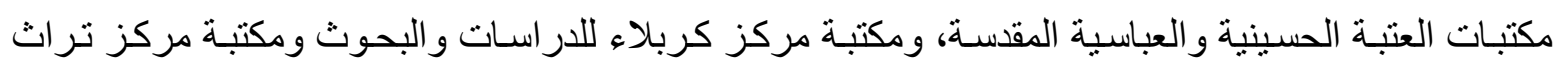
كربلاء ومركز العميد الدولي.

ويقلم الباحث جزيل شكره لكل من الدكتور حميد مجيد هدو مدير تحرير مجلة المصباح و الدكتور احسـان علي سعيد الغريفي مدير مركز تراث كربلاء ورئيس تحرير مجلة تراث كربلاء والأستاذ عبد الأمير عزيز القريثي مدير مركز كربلاء للدر اسات و البحوث ورئيس تحرير مجلة السبط لما قدموه من مساعدة للباحث

\section{المبمث الأول: نبذة عن اهم المجلات التي ثصدر عن العتبتين المسينية والعباسية المقدسة:}

اولاً: تمهميـ

تعد الصحافة اقدم وسيلة اعلامية كانت وماز الت لها الدور في تغيير العلاقات الانسـانية في المجتمع، كما انها تعد من اهم وسائل التبليغ والارشـاد والاعلام و النشر، وتهيئة الر أي العام وتوجيهه سواء في في مجال

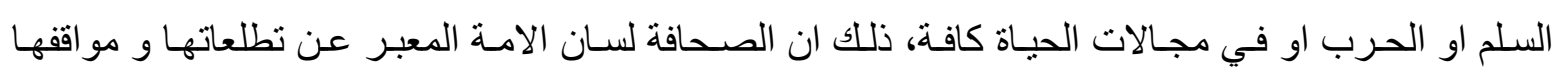
واهدافها السامية ، كما انها تمثل جانبا مهما من ثروتها الفكريـة والثقافيـة والحضـارية، و الحديث عن الصحافة الصنة في العر اق عامة وفي كربلاء المقدة على وجه الخصوص يتميز بطابع خاص ومن واقع حياة حافل بالحيويـة

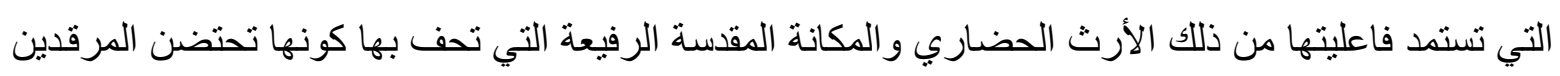
الطاهرين للأمام الثهيد الحسين ابن علي واخيه ابي الفضل العباس (عليهم السلام) وهو ما جعلها قبلة ومزاراً للمسلمين كافة وكل الأحر ار والثائرين من اجل الحرية والانسانية على مر التاريخ، كمـا اصبحت مركزاً هامـاً للإثـعاع الفكري و النهوض الثقافي ومحطة تحتضن عشرات الملايين من الزائرين و الو افدين اليها من كل

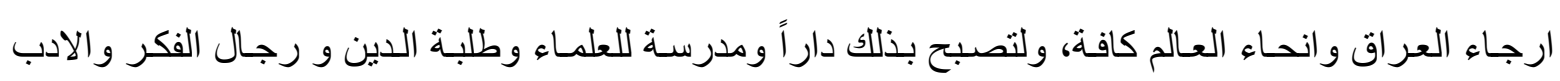
و السياسة و الصحافة.

تاريخ الصحافة في كربلاء يمتد لأكثر من مائـة عام ، اذ بدأ بظهور المطابع الحجريـة أولا و من ثم

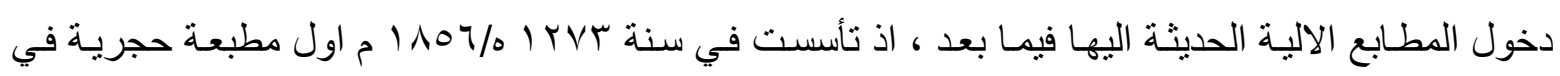
كربلاء لتكون بذلك ثاني مطبعة في العراق وقامت في بداية عهدها بطبع المطبو عات التجاريـة وكتب الادعية 


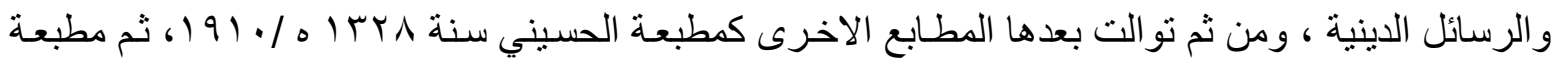

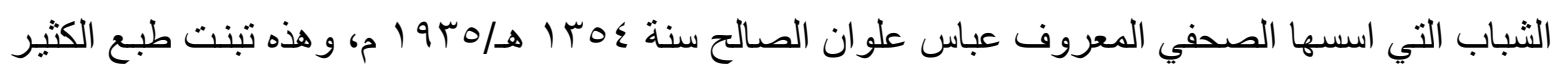
من الكتب التاريخيـة والدينية وكذلك الجر ائد والمجلات التي بـأت تظهر لأول مره في كربلاء مثل جريدة

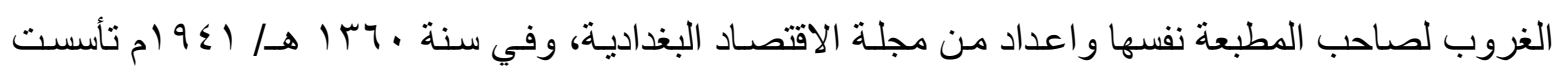
مطبعة الثقافة وفيها طبعت اعداد من جريدة الندوة الكربلائية وفي السنة ذاتها تأسست مطبعة الطف وصساحبها المرحوم ابر اهيم الكتبي ثم مطبعة اهل البيت وصساحبها الحساج جاسم الكلكاوي وفيها طبعت جريدة ومجلة وهية المجتمع الكربلائية.

ومع بدايات قيام نظام الحكم الجمهوري أواخر الخمسينات بدا ظهور المطابع الحديثة في المدن العر اقيـة الهامة الكبرى كـ بغداد و الموصل و البصرة و النجف الأشرف و أيضـا كربلاء المقدسة اذ تو الى تأسبس المطابع

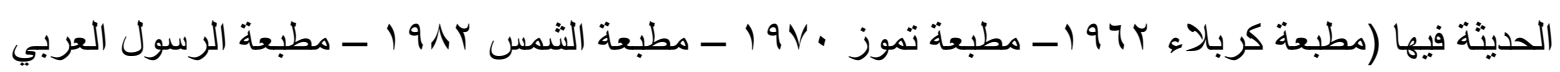

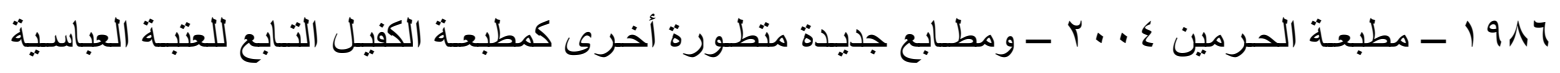
المقدسة، ومطبعة الوارث التابعة للعتبة الحسينية المقدة) حيث كان لاخولها دور الهاًاً في تطور الصحافة في العراق عموماً و كربلاء خصوصاً من حيث النوعية والمتانة اللغوية والأسلوب الصحفي و الكمية(؟). وللصـحافة في كربلاء تـاريخ كبيـر واكبـت فيـه المـدن العر اقيـة والعربيـة الكبرى كبغـداد و البصـرة

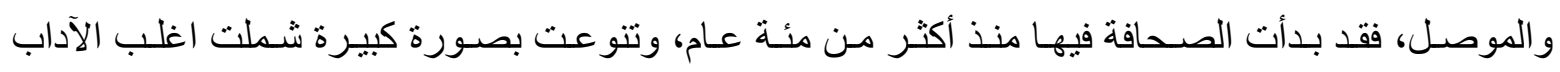

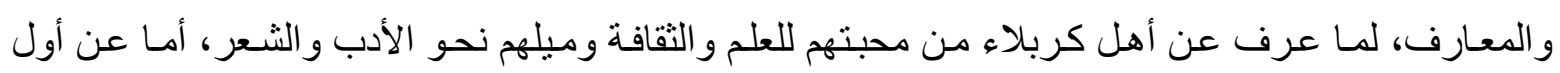

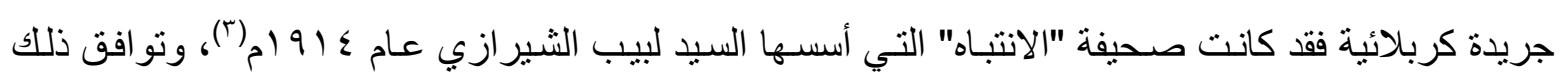

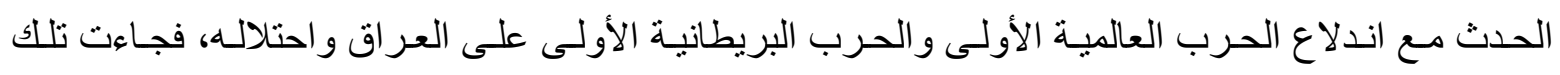

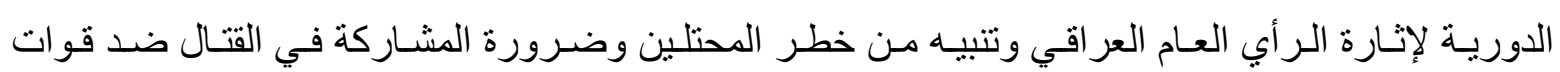
الاحتلال البريطاني، وللأسف لا يوجد في أرشيف دار الكتب و الوثائق العر اقية أية نسخة عن تلك الصحيفة. ثم

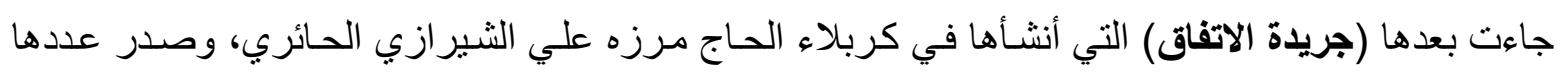

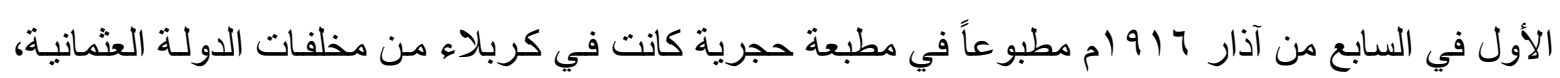
ولم تنتمر تللك الصحيفة طويلاً (๕)، ويبدو ان هدفها اقتصر على مقار عة المحتلين البريطانيين. وقد أثنى عليها الثاعر محمد حسن ابو المحاسن بقوله: (0)

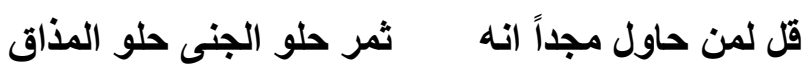 \\ ما جنته امة قبل ولا يجنتى الا بجد واتفاق}

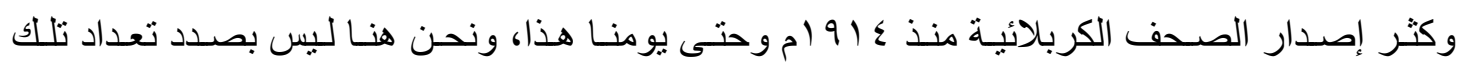

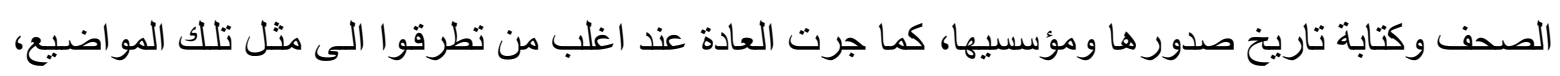
بل للتعرف على دور العنبة الحسينية والعباسية المقدة في النشر الاكاديمي، و على مـا تحويـه صحفها ودرجـة تأثثير ها في الر أي العام الكربلائي و المواضيع المهمة التي تناولتها سواء أكانت سياسية ام اجتماعية ام دينيـة،

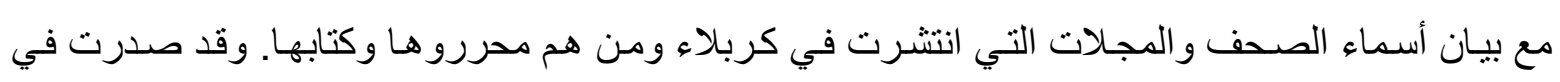




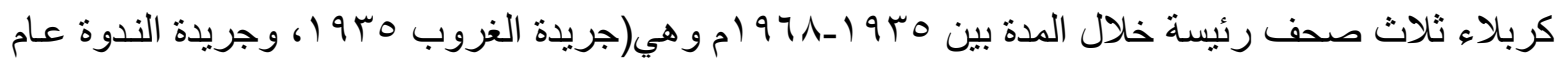

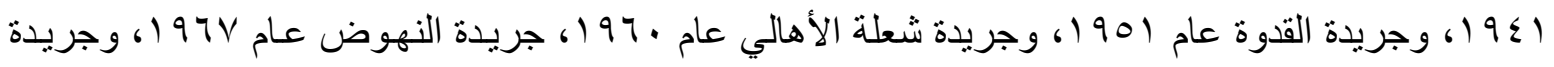

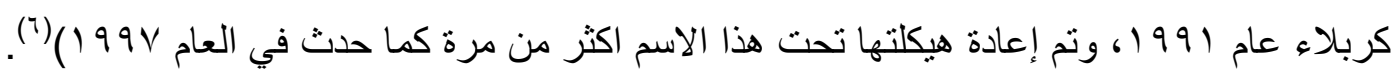

كانت هذه أهم الصحف التي صدرت في كربلاء، ولم تكن الصحف المجال الإعلامسي الوحيد في مدينـة

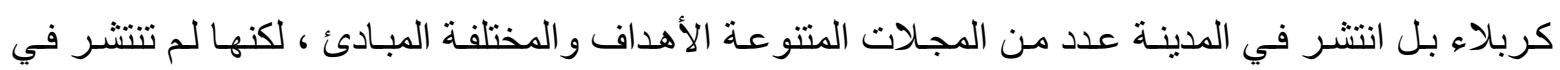
كربلاء الا في أو اسط خمسينيات القرن العشرين، على الرغم من صدور بعض المجلات المدرسية قبل هذا

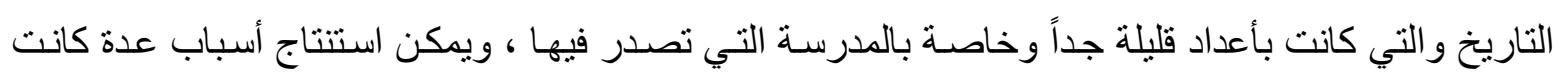

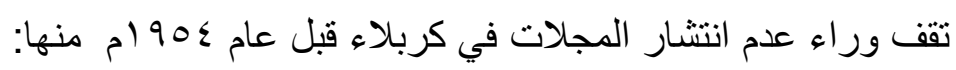

اـ ان الصحافة في العراق بصورة عامة اختزلت منذ بدايـة تأسبس الصحافة العر اقيـة في الصحف (الجرائد) ولم تتنشر المجلات في بغداد بصورة كبيرة، الا بعد تأسبس الدولة العر اقية الحديثة.

זـ لم تستمر اغلب الجر ائد الكربلائية في الصدور مدة طويلة باستثناء جريدة القدوة التي استمرت سنوات عدة ومع ذللك توققت عن الصدور بسبب نقص الأموال. بـ الخسارة المادية التي تعرض لها مؤسسو الجرائد في كربلاء سبباً رئيساً في ظهور المجلات في المدينة، فالمجلة يمكن ان تكون شهرية او نصف شهرية وبالتالي لا يكلف طبعها أموالاً كثيرة، كما انها تجذب فئب القراء لثر ائها الى حين صدور العدد التالي منها، عندها تبقى متوفرة في المكتبات مدة أطول، لبيع اكبر عدد منها. لهذه الأسباب أخذت المجلات تظهر في كربلاء بعد ان كانت الصحف هي الرائدة في السـاحة الثقافيـة.

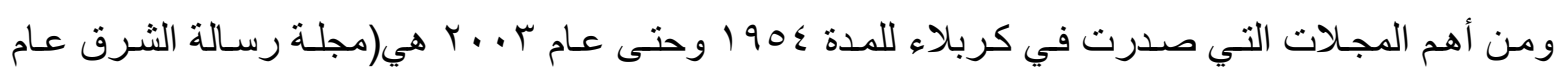

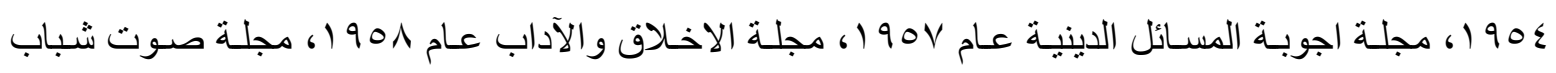

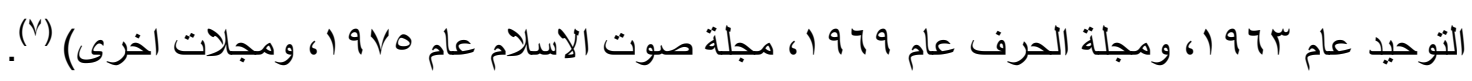
ثانياً: اهم المجلات التي تصدر عز العتبة الهسينية المقدسة: ان اهم مـا يميز صـحافة العتبـات المقدسة في كربلاء هي الثـمولية، أي انها لم تترك أي مفصل من

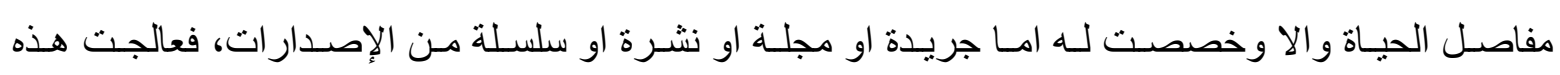

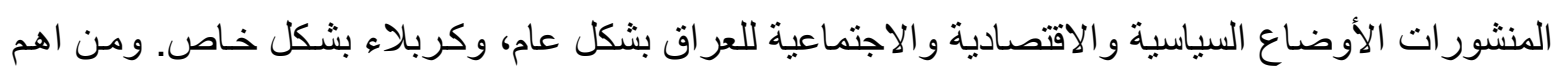
الإصدارات في العتبة الحسينية المقدسة:

ا - مجلة الإصلاح الحسيني: مجلة فصلية متخصصـة في النهضـة الحسينية وتعنى بالدر اسـات الدينية، تصدر عن مركز الدر اسات التخصصية في النهضـة الحسينية في النجف الاشـرفـ قسم الثؤون الفكريـة في العتبـة الحسينية المقدسة، استقي عنوانها من القول الوارد عن الامـام الحسين(ع) "و انمـا خرجت لطلب الإصـلاح في

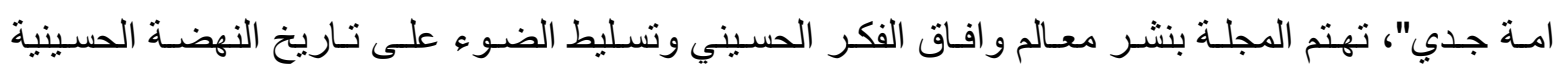

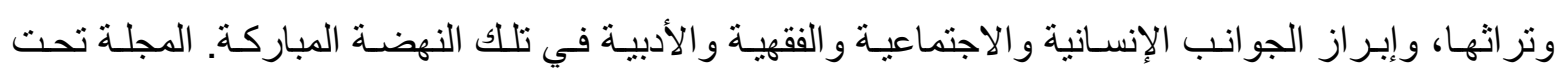
اشر اف الثيخ علي الفتلاوي ورئيس تحريرها الثيخ قيصر التميمي، رقم إيداع المجلة في دار الكتب و الوثائق 


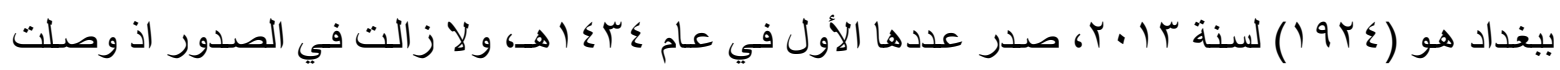

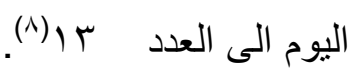

ץ- صدى القران: مجلة فصلية قر آنية ثقافية، تصدر عن دار القران الكريم في العتبـة الحسينية المقدسة، المجلة

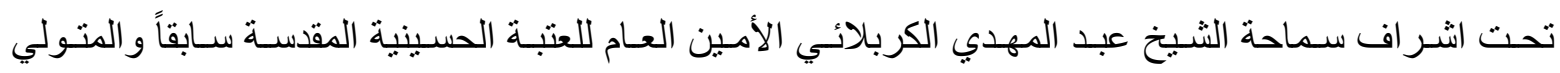

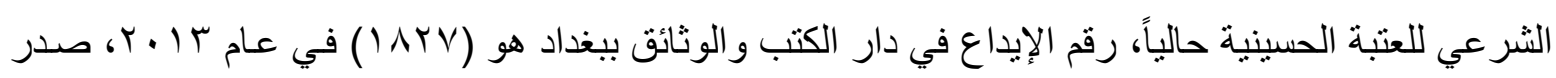

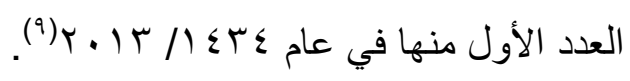
ب- مجلة الحفيظ: مجلة شهرية قرآنية، تصدر عن دار القران الكريم في العتبة الحسينية المقدة، تحت اشتراف

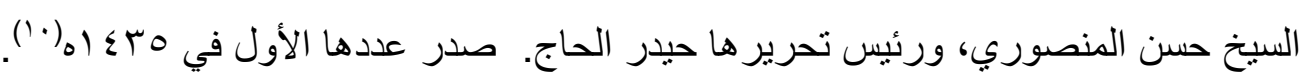

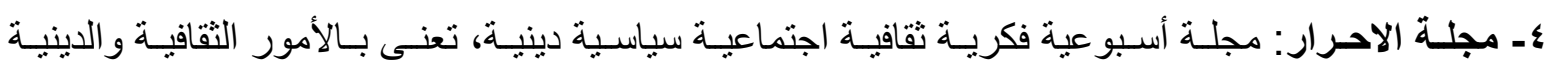
و الاجتماعية وتاريخ مدينة كربلاء المقسة وشؤون الاسرة وكل ما يتعلق بنشاطات واخبار و انجاز ات العتبات

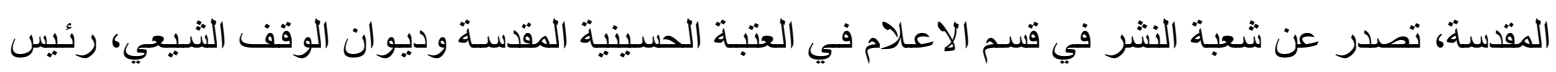

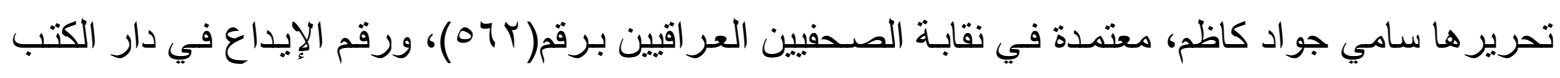

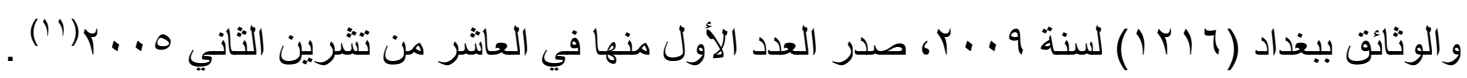
هـ مجلة الوارث: مجلة شهرية، ثقافية دينية، تعنى بفكر اهل البيت(ع)، تصدر عن شعبة الدراسات والبحوث

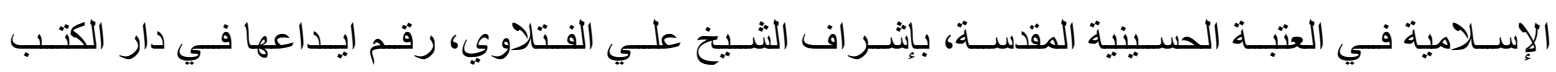

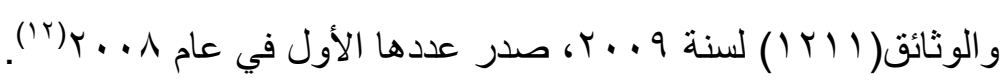

7- مجلة الروضة الحسينية: مجلة شهرية، تعنى بالثقافة الحسينية والثقافة الدينية العامـة، تصدر عن شعبة

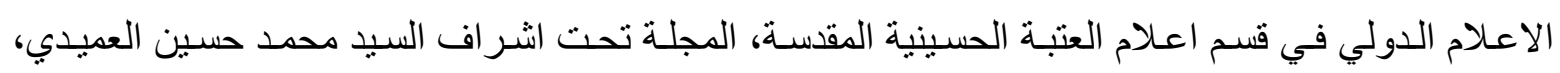

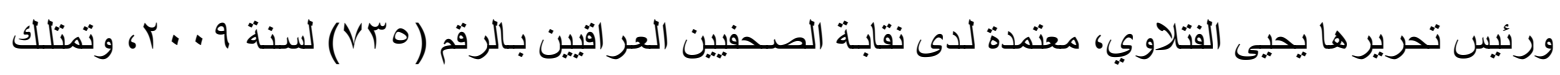

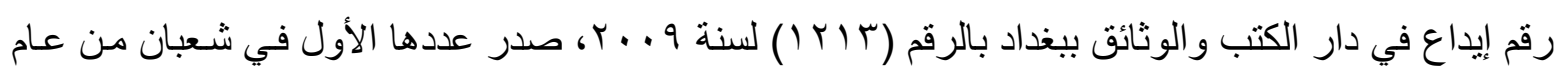

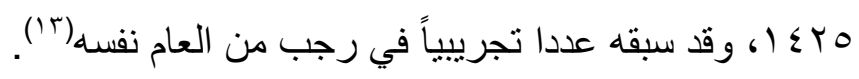
V- مجلـة المسرح الحسيني: مجلـة فصلية، تعنى بالثـأن المسرحي بشـل عـام والمسـرح الحسيني بشكل خاص، وتهدف من ذلك إيصال فكر النهضة الحسينية للعالم اجمع، تصدر عن شعبة النشر في وحدة المسرح

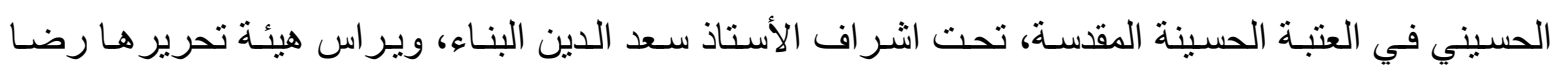

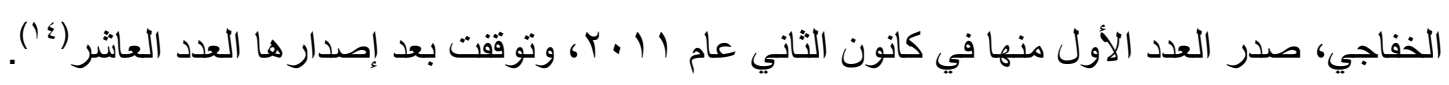
^- مجلـة صدى الخطباء: مجلـة شهرية، تعنى بثقافـة المنبر الحسيني، تهدف الى استذكار خطبـاء المنبر الحسيني ونشر تعاليم وفكر اهل البيت(ع)، تصدر عن معهد الامام الحسبن(ع) للخطابـة التابع للعتبـة الحسينية

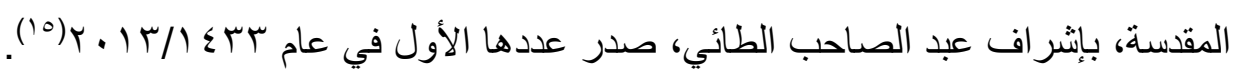


9ـ مجلة العطاء الحسيني: مجلـة ثقافيـة فكريـة نصف شـهرية، تعنى بتسلبط الضوء على المسيرة الثقافية

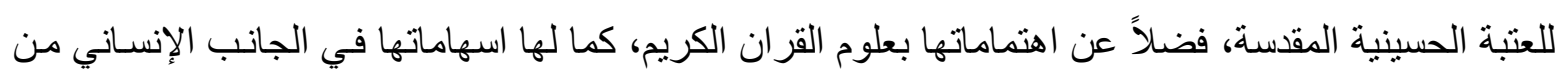
حيث تقديم المسـاعدات لأصـحاب الامـر اض المستعصسية، تصـدر عن شـعبة النشـر -قسـم الاعـلام في العتبـة الحسينية المقدسة، بإثر اف محمد حسين العميدي، صدر عددها الأول في اب 1 . . ب (7').

• اـ مجلة فتاة: مجلة شـهرية تعنى بثقافة الفتاة من سن البلوغ الى سن الخامسـة عشر، تصدر عن مدرسـة

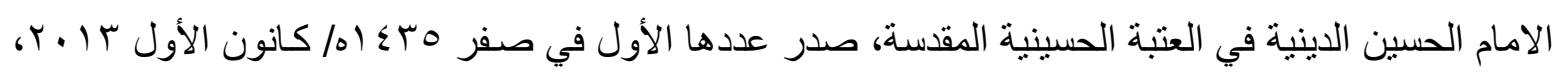

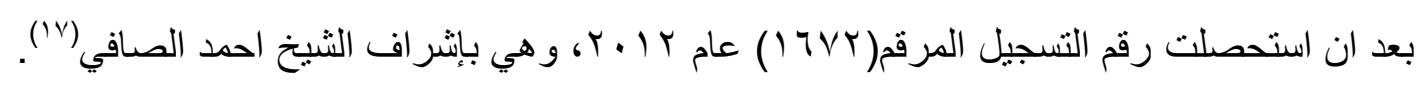
1 اــ العائلة المسلمة: مجلة شهرية، تعنى بثقافة العائلة المسلمة بكل مجالاتها من مخاطبة الواقع الاجتمـاعي

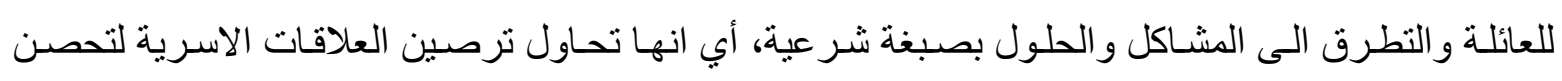
المجتمع من مشاكله الاسرية، تصدر عن شعبة النشر-قسم الاعلام في العتبة الحسينية المقدسة، صدر عددها

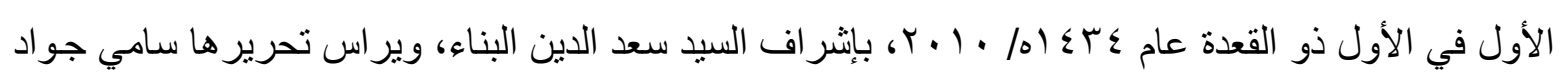

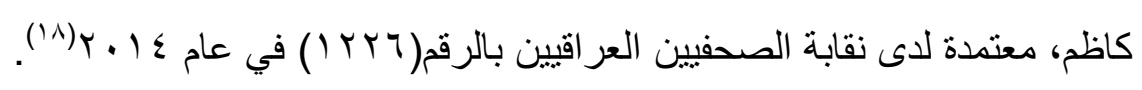

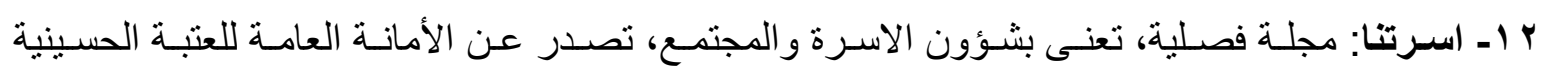

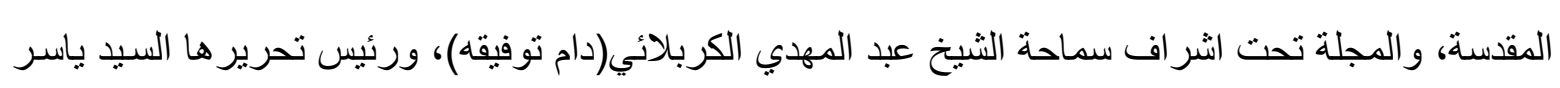

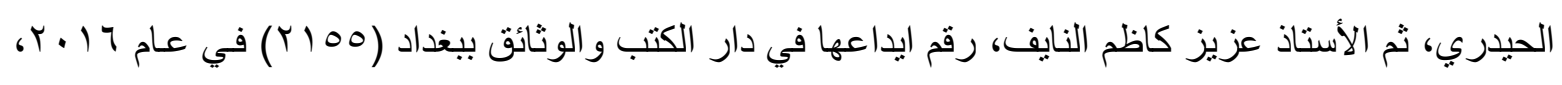
صدر عددها الأول في عام 0بـ اه(19). با ا - مجلـة شباب: مجلـة فكريـة ثقافيـة عامـة، تعنى بشؤون الثباب، تصدر عن مركز كربلاء للار اسـات و البحوث في العتبة الحسينية المقدة وجامعة المصطفى العالمية في قم المقدسة، بإثـر اف الثيخ عبد المهدي

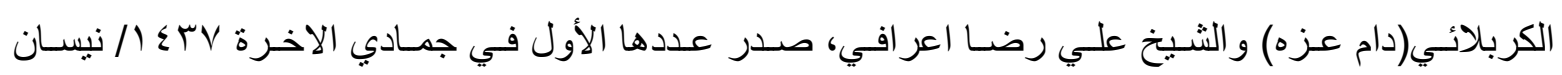
$(r \cdot)^{r} \cdot 17$

ـ ا - مجلـة النهضـة الحسينية: مجلـة فصلية، تعنى بالثـؤون الإسـلامية والحسينية، وتهدف المجلـة إلى نقل

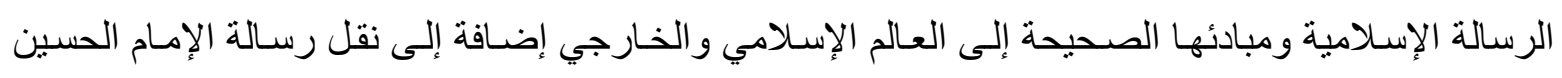

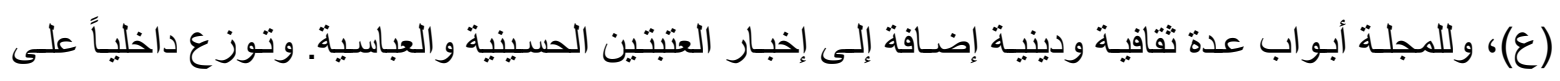

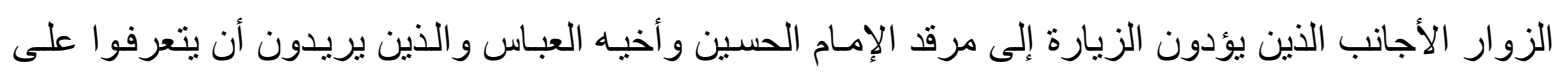

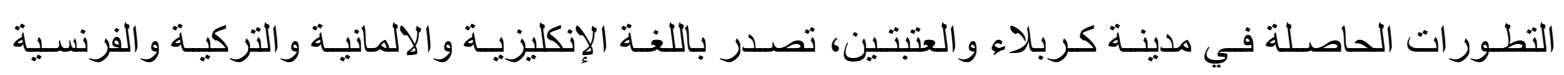

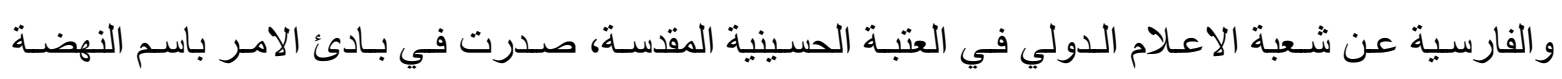

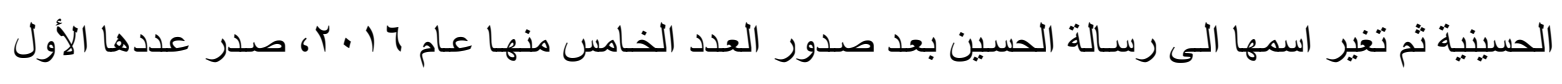

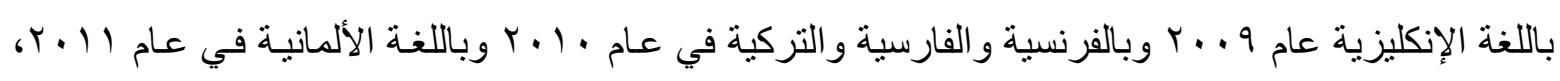

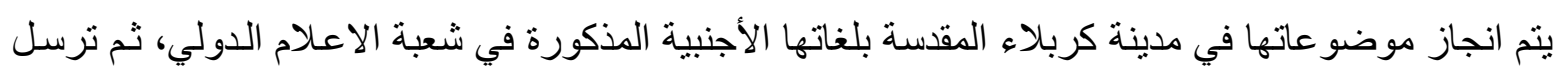


عبر البريد الاليكتروني الى الدول المراد توزيع النسخ فيها من اجل طباعتها ومن ثم توزيعها هناك عن طريق مكاتب العتبة الحسينية في اوربا وامريكال(r).

ه اـ مجلة فتية الخير: مجلة شهرية، تعنى بثقافة وشؤون الفتية من( • ( ـ 1 عام)، تصدر عن اعلام مدرسـة

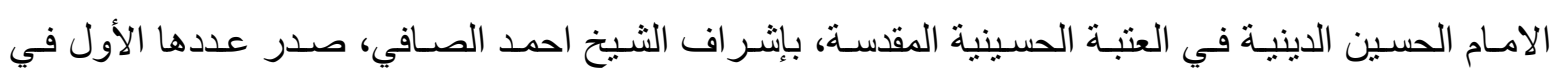

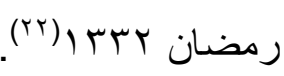

1 ا ـ مجلة الحسيني الصغير: مجلة شـهرية، تصدر عن رعايـة وتتميـة الطفولة في العتبـة الحسينية المقدسة،

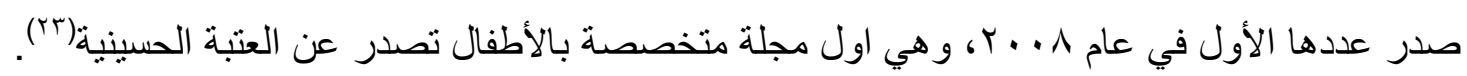
V ا - مجلة براعم: مجلة شهرية تعنى بالطفل وبثقافته وكيفيـة التعامل مـع الأطفال بمبوجب التعاليم الإسـلامية

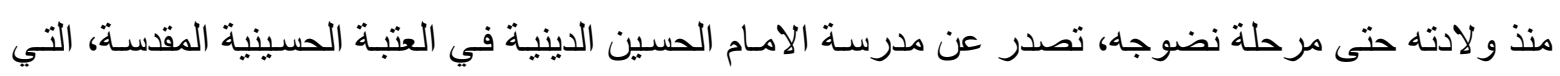

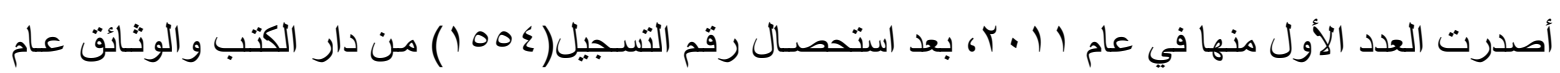

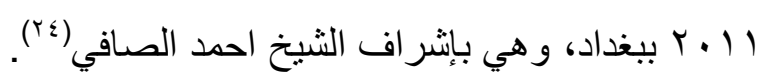

1 اــ البعد الاخر لنصـائح المرجعيـة: نشـرة لتوضيـح الابعـاد المهــة مـن النصـائح والتوجيهات التـي تقدمها المرجعية الدينية العليا في النجف الاشرف الى المقاتلين في الجيش العر اقي و الحشد الثعبي وهم يسطرون أروع صور التضحية والفداء في ساحات الجهاد ضد عصابات داعش الإرهابية(ror).

9 اــ الرايـة: نشـرة ثقافيـة عامسه نصف شـهرية خاصـة بمنتسبي العتبـة الحسينية المقدسة صدرت عن اللجنـة الإعلامية في العتبة عام سبـ أهـ، ساهم في تحرير ها نخبة من منتسبي الحضرة المقدسة منهم :علي الجبوري

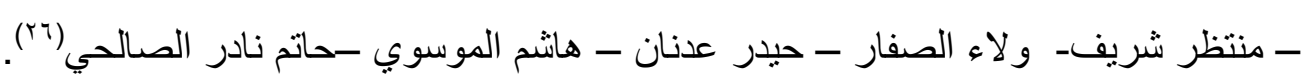
• • ـ منشـورات شعبة النشر/ قسم الاعلام-العتبة الحسينية المقدسة: صدرت عن هذه الثـعبة الكثير من الإصدار ات وفي مختلف المجالات، الثقافية والاجتماعية والسياسية والاقتصادية، وسير الاعلام والثعر، منها: (حبيب بن مظاهر الاسدي)، (علمتنا كربلاء)، (فأمسا اليتيم فلا تقهر)، (الحسن المجتبى(ع) رسـالة وجهاد) للاكتور سلمان هادي ال طعمة، (راقدون عند العباس(ع)) تأليف سـامي جواد الكاظمي، (عالمية الأربعين)،

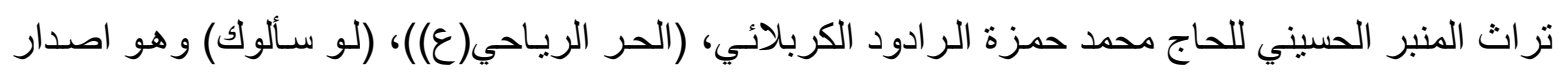

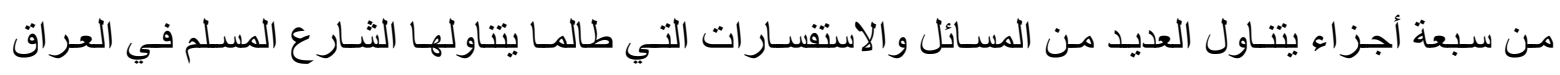
وخارجه، من اعداد سامي جو اد كاظم، وطبع ست طبعات في مطبعة الوارث في العتبة الحسينية المقدسـة، (الكتب الاربعة) (بيان المرجعية) يهتم بالآراء العر اقية والعربية والعالمية حول البيانات و التوجيهات الصـادرة

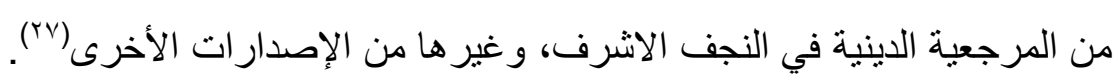
ثالثاً: اهم المجلات التي تصدر عن العتبة العباسية المقدسة: اـ صدى الروضتين: بعد تغيير نظام الحكم في العراق عام ب . .ب اخذت المرجعية المباركة في النجف الاشرف على عاتقها إدارة العتبات المقسـة، فكان لابد من اصدار توثيقي يوثث كل مراحل التطور الفكري و الثقافي و العمر اني و الخدمي الحاصل في العتبات المقدسة، فكان اول الغيث صدى يحتضن التواريخ القاً 


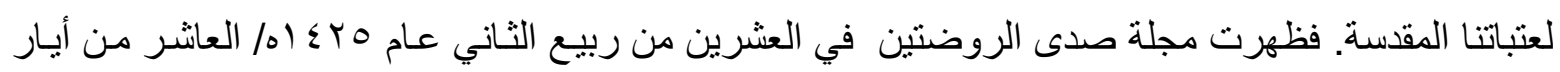
ـ . . r، و هي مجلة إسلامية عامة مستقلة، تعنى بالثقافة الحسينية والثقافة العامـة وتعتمد الخطاب الإسـلامي التنويري الذي يرصد القضايا الأساسية المر اد توضيحها، ومعالجة ما يكتنفها من ملابسـات أو غموض، حسب

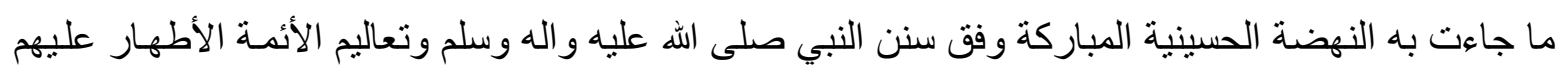
الصلاة و السلام. وصدى الروضنتين مجلة نصف شـهرية تصدر عن فتشم الثؤون الفكريـة والثقافية في العتبـة العباسية المقدسة/ شعبة الاعلام، رئيس تحريرهـا هو الأستاذ علي حسين الخباز ، ومدير تحرير هـا الأستاذ

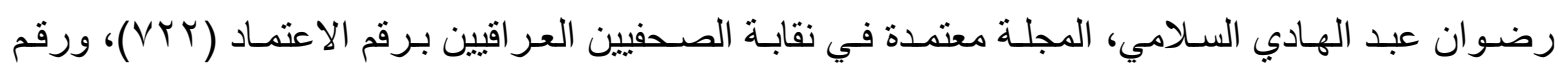

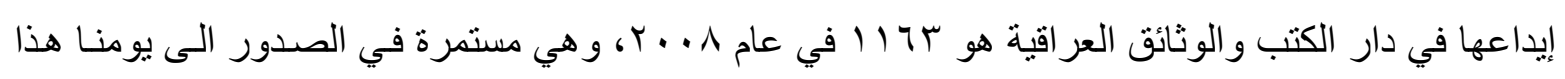

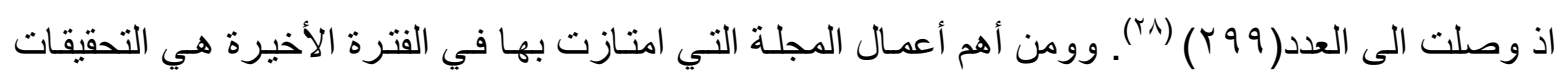
الاجتماعية التي تخص حياة المجتمع العر اقي، ومشـاكل وهموم الثـعب العر اقي وتسليط الضوء على الحلول

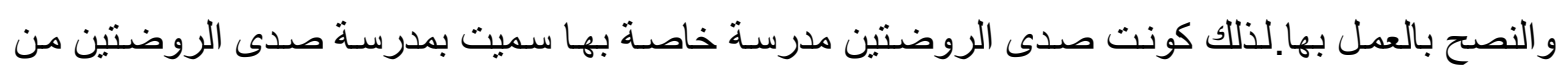

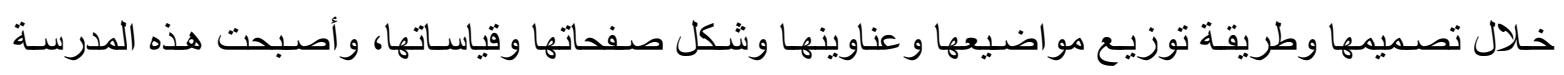
أنموذجا لبافي العتبات و المؤسسات الدينية.

r- مجلة أرشيف حضارة كربلاء: مجلة فصلية وثائقية مصورة تعنى بتراث كربلاء و الموروث الحسيني، تصدر عن قسم الثؤون الفكرية و الثقافية- مركز تراث كربلاء في العتبة العباسية المقدسة وتحت اشر اف السيد

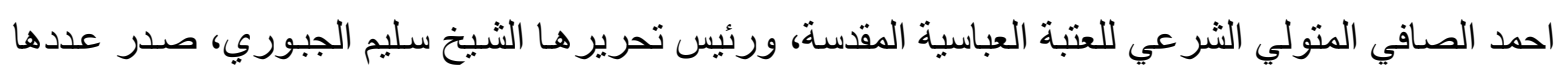

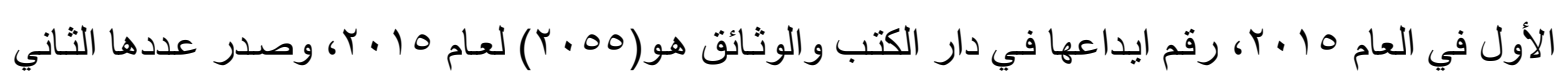

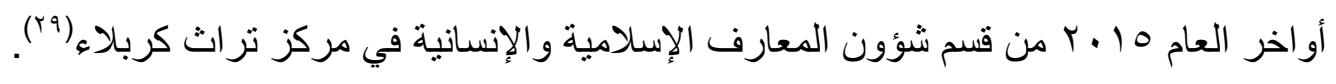
r- مجلة الغاضرية: مجلة فصلية ثقافية تعنى بتراث مدينة كربلاء المقدسة، تصدر عن قسم شؤون المعارف الإسـلامية والإنسـانية-مركز تراث كربلاء في العتبـة العباسية المقدسـة، صـدر عددها الأول في ذو القعدة

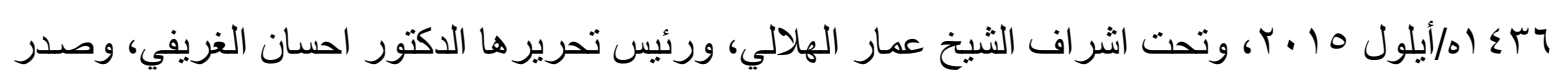

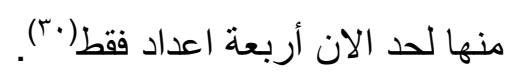
ع - مجلـة كفوف: مجلة فصلية تعنى بنشـاطات ومشـاريع و اقسـام العتبـة العباسية المقدسة تصسدر عن قسم

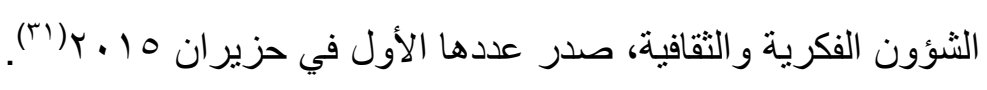
هـ صـدى المناسبات: سلسـلة مـن الإصــار ات الخاصـة بمناسبة و لادة الائمـة و المعصـومين(عليهم السـلام)،

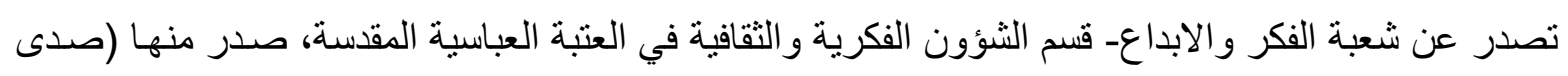
الرسالة، صدى الزهر اء، صدى ام البنين، صدى المرتضى، صدى الحور اء، صدى الحسن المجتبى، صدى ولى

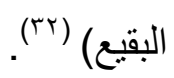


جـ صدى عاشوراء: مجلة ثقافية خاصة بشهر محرم الحر ام، تصدر عن شعبة الاعلام- قسم الثؤون الفكريـة و الثقافية في العتبة العباسية المقدة، ويتم اعدادها وتحرير هـا من قبل وحدة جريدة صدى الروضتين، المجلة

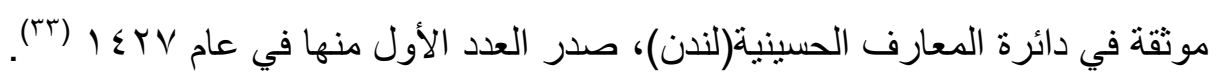
V- صدى الأربعين: مجلة ثقافية خاصة بشهر صفر الخير، ويتم اعدادها وتحريرها من قبل وحدة جريدة صدى

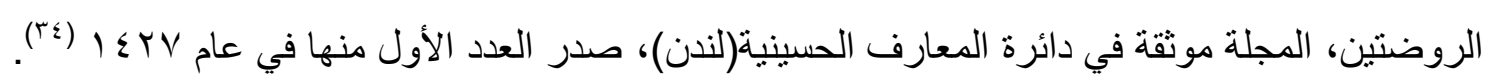
^- صدى شعبان: مجلة ثقافية خاصة بذكرى و لادة الأقمار الثعبانية، تصدر عن شعبة الاعلام- قسم الثؤون الفكرية و الثقافية في العتبة العباسية المقسة، صدر عددها الأول في عام V .. . ץ(ro). 9-صدى العسكريين: نشرة ثقافية خاصة بذكرى فاجعة سامر اء، صدرت عن شعبة الاعلام في قسم الثؤون

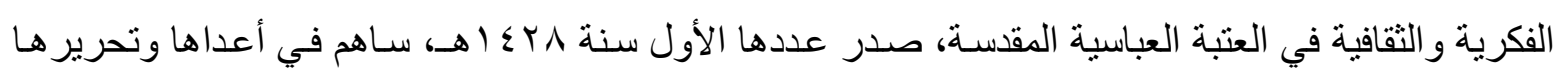
و إخر اجها العاملون في مجلة(صدى الروضنتين)،ضمن العدد الأول مجموعة من الدر اسـات و البحوث التي

تناولت العسكريين وتأثير فاجعة تهديم مرقدهما من قبل الزمر التكفيرية في نفوس المسلمين في العالم(بَ). • ــ مجلة العرفان: مجلة قرآنيـة فصلية، تصدر عن قسم شؤون المعارف الإسـلامية والإنسانية في معهد القران الكريم في العتبة العباسية المقدسة، بإثر اف الثيخ عمـار الهلالي، رقم ايداعها في دار الكتب و الوثائق

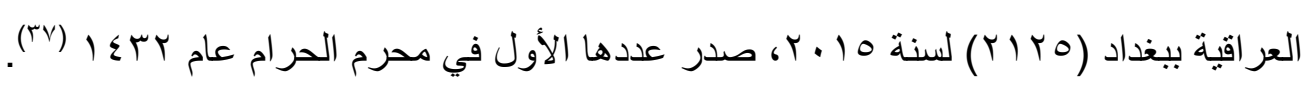

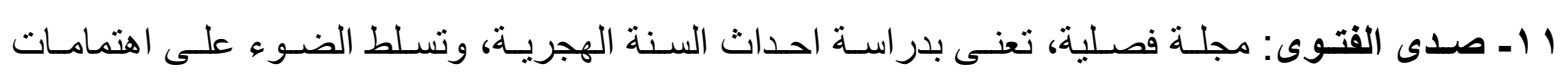
وتوجيهات المرجعيـة الدينيـة في النجف الاشـرف، تصدر عن شعبة الفكر والابـداع-قسم الثؤون الفكريـة

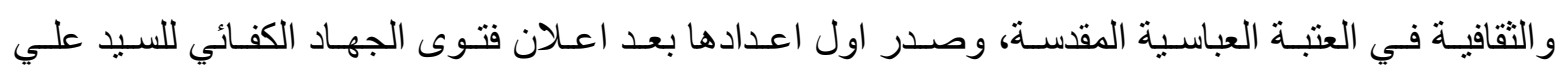

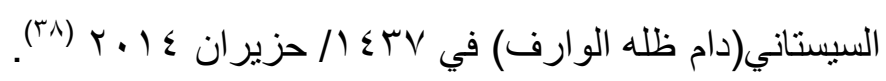

ب ا ـ مجلـة بنـات الهـدى: مجلـة فصلية تصدر عن العتبـة العباسية المقدسـةقفسم الثـؤون الفكريـة والثقافيـة بالتعاون مع نخبة من طالبات الجامعات العر اقية(؟9).

بـ ا - مجلة رياض الزهراء: مجلة شهرية تعنى بالمر أة والاسرة المسلمة، بكل ما يتعلق بهما من شؤون تربويـة

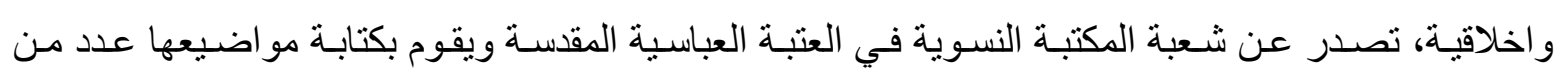

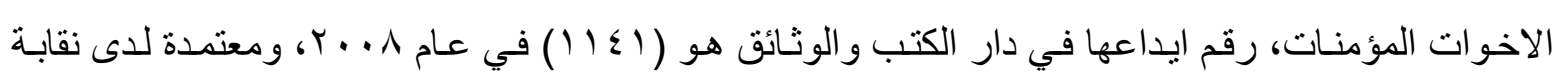

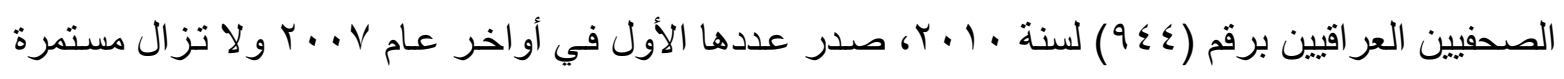

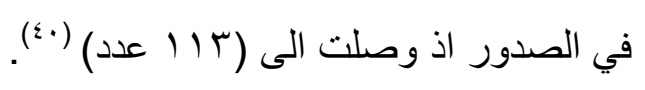

ء ا - مجلة عطاء الثباب: مجلة اجتماعية فكرية ثقافية، تعنى بالثقافة العامة وبالمجتمع الجامعي و الثبابي على وجه الخصوص، تصدر عن شعبة الفكر والابداع- قسم الثؤون الفكرية والثقافية، حيث يثارك في الكتابة فيها أساتذة وطلبة من الجامعات العر اقية والعربية، صدر العدد الأول منها في عام • ( • ب، ورقم ايداعها في دار

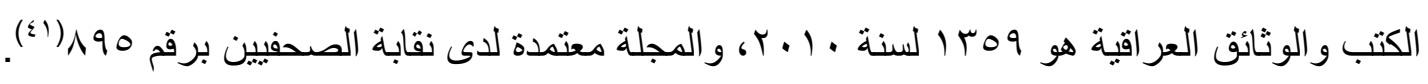


10 ـ سلسـلة المناهل العقائديـة للثباب: سلسـلة أجز اء تهتم بالشؤون العقائديـة لتو عيـة وتثقيف الثباب المؤمن بأسلوب عصدري خـال من التعقيد ومن الأمثلة على بعض عنو انـات اصدار اتها "معرفة المعاد"، "من اجل جو اب ناجح" (זr).

1 ـ ـ سلسلة المناهل الأخلاقية للثباب: أيضا سلسلة تهتم بتو عية الثباب المؤمن ومن اهم اصدار اتها "صلة

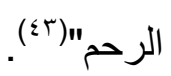

V ا - سلسلة مناهل الطف للشباب: سلسلة أجز اء تهتم بالثؤون الأخلاقية لتو عية وتثقيف الشباب المؤمن متخذة

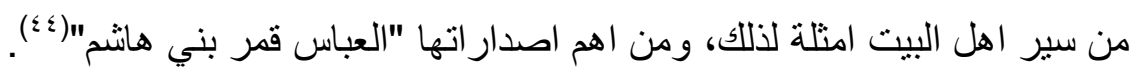
1 اـ مجلة الرياحين للأطفال: هي عبارة عن مجموعة من قصص مصورة ومجلات خاصسة بالطفولة، والتي تسـاهم في بنـاء الطفل وفق رؤى العقيدة الإسـلامية، جـاءت تسميتها تيمنـاً بريحـانتي رسول الله (ص) الحسن و الحسين(ع)، تصدر عن شـعبة الاعلام- وحدة الرسم في قسم الثـؤون الفكريـة والثقافيـة في العتبـة العباسية

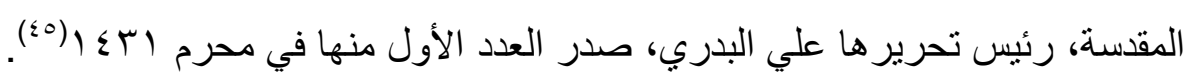

9 ا ـ إصدارات الرياحين الخاصة: مجموعة مما تصدره العتبة العباسية المقدة من قصص ومجلات خاصـة بالطفولة) (1).

• ץ- نشرة رياحين الكفيل: هي نشرة أسبو عية ثقافية، تصدر عن الثؤون الفكريـة والثقافيـــ شعبة الطفولـة

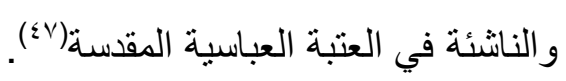

ابـ اشبال الكفيل: تصدر عن قسم الثـؤون الفكريـة والثقافيـةـ شعبة الطفولة و النانشئة في العتبـة العباسية المقدسة:(^^).

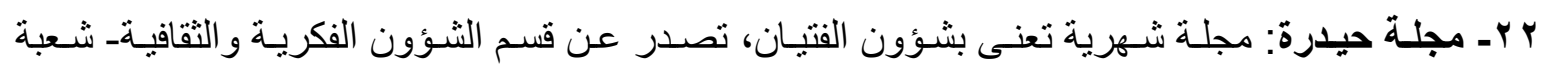
الطفولة والناثنئة في العتبة العباسية المقدسة( ب r- سلسلة سبل الرشاد: تصدر عن قسم الثؤون الفكرية والثقافية في العتبة العباسية المقدسة، تختص هذه السلسلة بقصص الذين اختاروا خط التشيع من بين الخطوط الإسلامية لأنه يمثل الخط الإسلامي الصحيح الذي امر به الله ورسوله، وهو خط اهل البيت عليهم السلام(.0.) § ז- سلسلة بناء الشخصية الناجحة: تعنى بفكر الانسان وكيفية بناء شخصيته، تصدر عن شعبة الدراسـات و النشرات في قسم الثؤون الفكرية والثقافية في العتبة العباسية المقدة ومن إصدار اتها مثناًا الوعي والادر اك "تكسير زجاجة الو هم"( و). ه بـ سلسلة نفحسات تربويـة: تصدر عن شعبة الدراسـات والنشرات في قسم الثـؤون الفكريـة والثقافيـة في العتبة العباسية المقدسـة، وهي مختصـة بمناقتـة ودر اسـة الجو انب التربويـة للفرد في المجتمع العر اقي، ومن

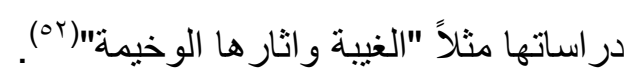


צ ז- سلسلة المشتركات الفقهية: تختص هذه السلسة بتفنيد الثبهات التي تثير ها الفرق التكفيرية استناداً على ادلة من الكتاب و السنة، وبما عمل بـه الأنبياء و الاولياء والصحابة، بل كافة المسلمين ومن امثلة اصدار اتها التي تعد بالعشرات "الحلف بغير الله"(ro).

V Vـ قراعات انطباعيـة فـي نهج البلاغـة: تصـدر عن قسـم الثـؤون الفكريـة و الثقافيـة في العتبـة العباسـية

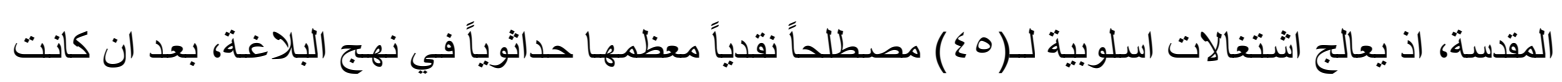
اغلب معالجات العلماء للاشتغالات النقدية في نهج البلاغة في المحور التفسيري، الديني، الفلسفي(هُ). ^r ـ نشرة الكفيل: نشرة أسبو عية ثقافية تختص بالمو اضيع العقائدية، الفقهية، الأخلاقية، والقر آنية و غيرهـا، تصدر عن وحدة الدر اسـات و النشـرات التابعـة لثـعبة الاعـلام في قسـم الثـؤون الفكريـة و الثقافيـة في العتبـة العباسية المقدسة(00).

و بـ سلسـلة دليل المحساور: تعتبـر هذه السلسـلة دليلاً مسـاعداً للمحساور الذي يريـد اثبـات العقيدة الإسـلامية

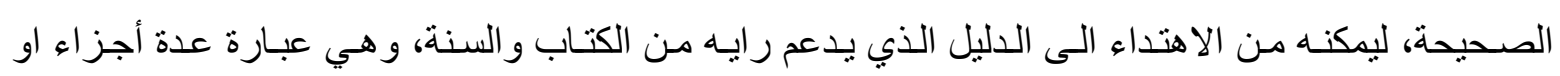
مجلدات(07).

• ـــ منشورات المكتبة: تقوم شـعبة المكتبـة في العتبـة العباسية المقسـة بتحقيق عدد مـن الكتب في العقيدة و السـيرة و الادب و التـاريخ، ووضـعت هذه الكتب بعد التحقيـق تحت يـد القـارئ في الموقع الرسـمي للعتبـة المقدسة، وصدر منها الكثير ما يخص تاريخ المدن العر اقية منها، "كربلاء في مجلة لغـة العرب" ثنلاث أجزاء

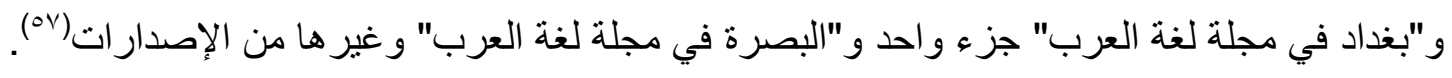
اسـ نشرة الخميس: نشرة أسبو عية تختص بالمو اضيع الثقافية والأدبية والتاريخية والاجتماعيـة ونشر فكر

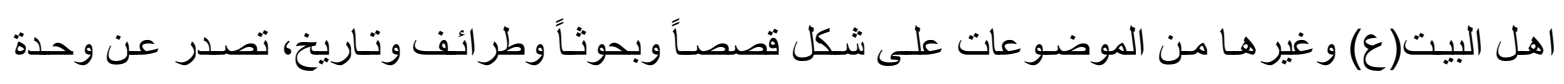
الدر اسات و النشرات التابعة لثعبة الاعلام في قسم الثؤون الفكرية و الثقافية في العتبة العباسية المقدسة، صدر وندر

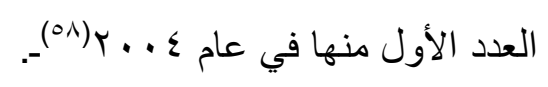
r r- منشورات إذاعة الكفيل: تقوم شعبة الإذاعة في العتبة العباسية بإيصال بر امجها كتابياً الى ايدي الذين لم يسعفه الوقت لسماعها وذلك بطباعة بعض بر امجها، وذلك بطباعة بعض بر امجها و اصدار ها ككر اس(هون. بrــ نشـرات مركز الاراسـات الاسـتراتيجية: مجموعـة مـن الإصـدارات الخاصـة بالاستشـراق و المستشـرقين، ونشرات لرصد اهم ما يدور في الساحة السياسية والثقافية من دراسـات وبحوث، وهو جزء من قسم الثـؤون

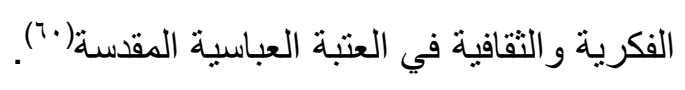
ع سـ نشرة اهل الثغور: نشرة أسبو عية تختص برصد الاعلام الحربي للحشد الثعبي، تصدر عن قسم الثـؤون الفكريـة والثقافيـة في العتبـة العباسية المقدسة، وهي مختصـة بمتابعـة توجيهات المرجعيـة الدينيـة في النجف الاشرف للمقاتلين العر اقيين في ساحات القتال، كما تتابع اخبار انتصـار القوات الأمنيـة العر اقيـة وقوات الحشد وفي 
المقدس على قوى الظلام داعش ومن لف حولها في منـاطق العراق الحبيب، خصوصـا بعد سبطرة هذه

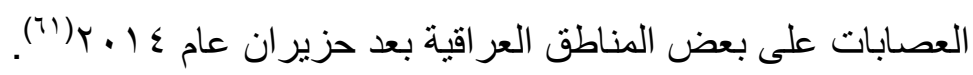

هـ ــ رد الشمس: مجلة فصلية ثقافية عامة، تعنى بالتراث الحلي، تصدر عن قسم شؤون المعارف الإسـلامية و الإنسانية في مركز تراث الحلة التابع للعتبة العباسية المقدة، بإنر اف مدير القسم الثيخ عمـار الهلالي، رقم

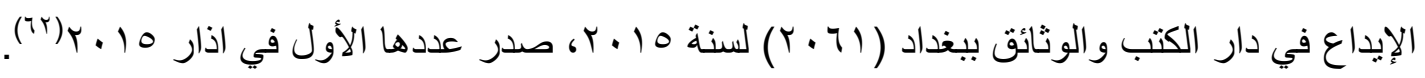
צب- إصدارات متفرقة: تتضمن هذه السلسلة مجموعة من الكراسـات في مجلات مختلفة، في الفقه والعقائد

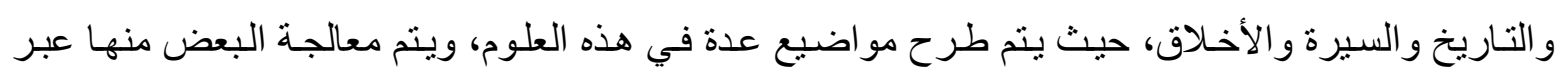
در اسات تخصيصية يعدها أساتذة اكفاء ومن ذوي الاختصاص.

\section{المبمث الثاني: دور مجلات العتبة المسينية المكمة في النشئ الاكاديمي:}

1- مجلة المصباح المهكمة:

مجلة فكرية فصلية محكمة، تعنى بالدراسات والأبحاث القرآنية، تصدر عن دار القران الكريم في العتبـة الحسينية المقدسة، بإثر اف سماحة الثيخ عبد المهدي الكربلائي، وير أس تحرير هـا الأستاذ محمد علي هدو ومدير تحرير هـا والعلاقات العامـة الدكتور حميد مجيد هدو. تكلم سماحة الثيخ عبد المهدي الكربلائي (دام عـزه) المشـرف العـام على مجلـة المصـباح عـن سـبب اصــار المجلـة بقولـه" المصـباح...انطلاقة لصـياغة الثخصية القرآنية الغائبة عنا، وبعد: ان الثخصية القرآنية بجميع ابعادهـا المعرفية والاجتماعيـة والأخلاقيـة و السياسية والحضارية قد افل نجمها من سمائنا و غابت مقوماتها عن ارضنا... لقد شهر و عاش مجتمعنا غياباً و اضحاً لاهم أسس ومقومـات الثخصية القر آنية بمعارفها وخلقها وحضـارتها وقيمها فكان التعاضد و التآزر

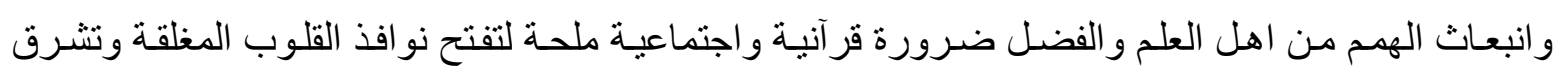
صفحات العقول الملبدة نحو صياغة شخصية تكون مصداقاً لأشر اف الامـة الذين هم حملة القران حقاً فكانت

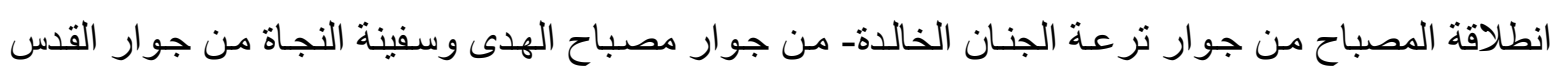
و الطهر و الثورة والابـاء لكي تتجاوب وصدى تلك الحناجر التي ترنمت بآياته هـ معثوقها الذي تاقت اليه بهيام ووله. حناجر أصحاب سيد الثهـداء(ع) ليلة عاثـور اء- وهكذا كانت و لادة المصباح من جوار مصباح

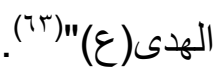

كما اكد الأستاذ محمد علي هدو رئيس تحرير مجلة المصباح "ان دار القران الكريم في العتبة الحسينية المقدسة يوم اقرت الخوض في مخاض القران، انمـا ارادت ان يكون لها شـرف المسـاهمة في خدمـة كتاب الله العزيز ولم تكن لها نية منافسة لجهة او أخرى...كما لم يكن لها هدف في اظهار المواهب على سبيل الريـاء، فقد أقدمت على ما أقدمت عليه، وهي مفعمة بالأعجاب والتقدير لكل الجهود الخيرة التي تتطلق من هنا وهنالك

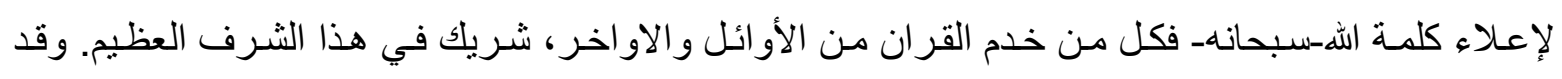

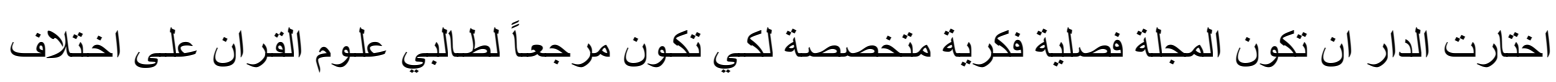
مستو ياتهم العملية ومصدراً محكماً لكل من به نهم لمعرفة القران العظيم، هذه النزعة التي استعر اوار هـا في 
نفوس الثباب المثقف المتطلع الى الحقيقة اليوم، انها تمثنل وجبـة فكريـة غنية لعقول كل المستتيرين بهدى القر ان و على اختلاف مستوياتهم ومشاربهم ومذاهبهم (؟ج).

تتو عت موضو عاتها بين بحوث علمية اصيلة ونصوص محققة، وردود نقدية، وعرض لمؤلفات قر آنية،

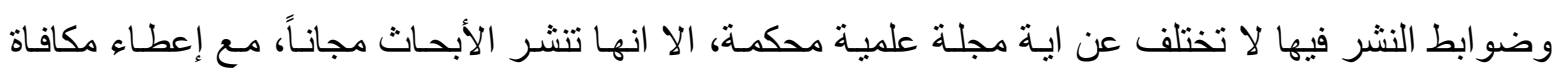

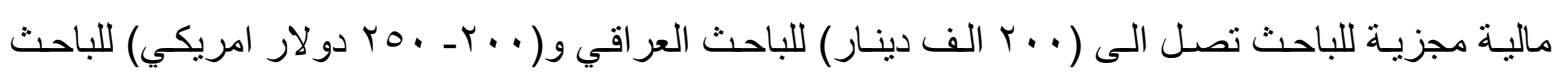
العربي والاجنبي مع عدد من المجلة المنشور فيها البحث.

تتألف هيأتها الاستشارية والتحريرية من مجمو عة من الأسـاتذة الاكفاء والمختصين بعلوم القران ومن مختلف الجامعات الأجنبية والعربية والعر اقية، فمنهم من (سوريا ومصر وايران). وقد صدر العدد الأول منها

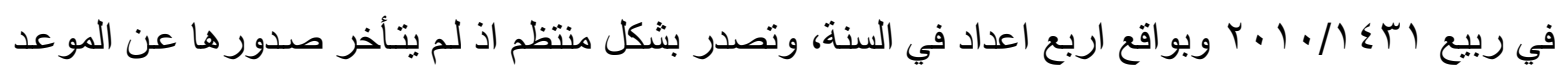

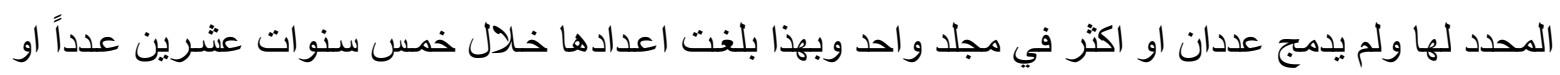

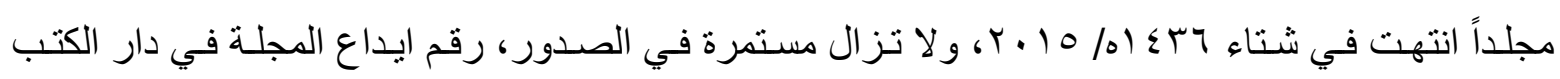

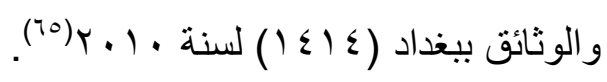

كانت المجلة بعنوان (مجلة فكرية فصلية متخصصة) من العدد الأول حتى العدد الخـامس عثر، بينمـا أصبحت في العدد السادس عشر تحت عنوان(مجلة علمية فصلية محكمة) بعد نبلها التحكيم العلمي من وزارة

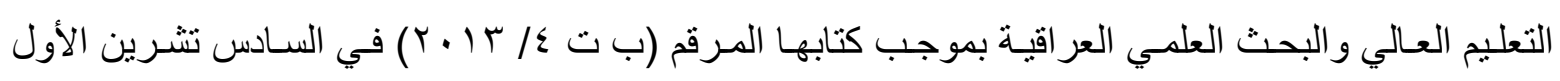

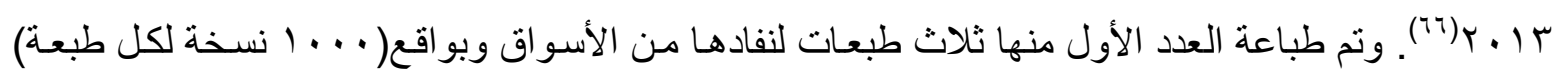

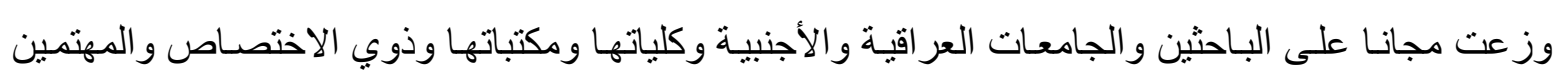

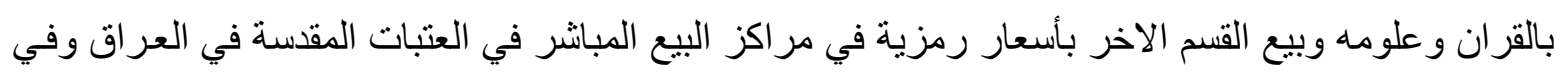

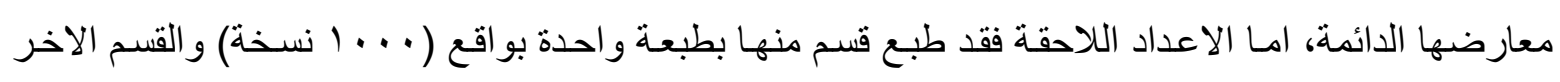

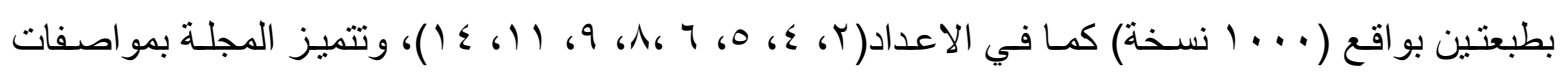
فنية عالية، من حيث طباعتها وجودة الورق المستخدم، وجمالية المظهر اذ حرص القائمين عليها تحديد لون

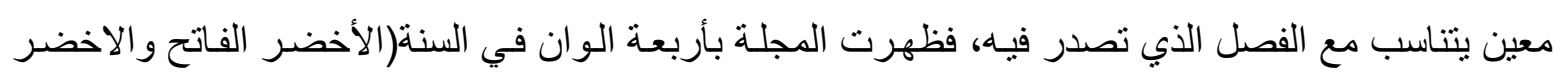

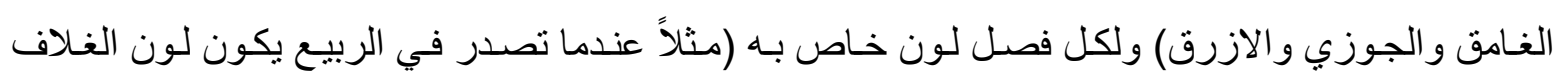

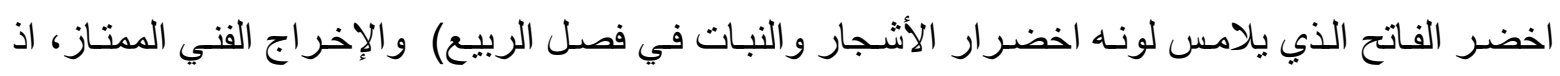
طبعت الاعداد من(الأول الى الثامن) في لبنان، ومن (التاسع الى الثالث و العشرين) في ايران، ومن (الثالث

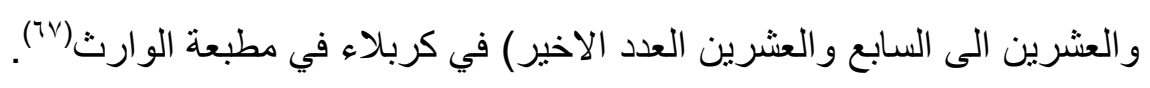
نالت مجلة المصباح استحسان الكثير من الناس سواء كانوا اكاديميين او رجال دين او مهتمين بشؤون القران و علومه، ومنهم الثيخ الطيب شيخ الازهر الذي طلب الأعداد الكاملة للمجلة لرفد مكتبـة الازهر بها،

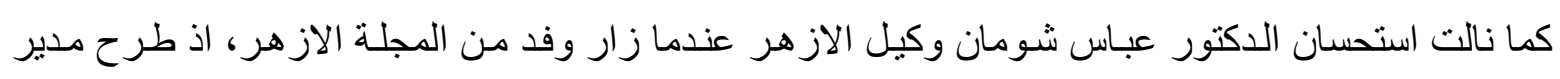
المجلة سؤالاً عليه "هل تعرف هذه المجلة سنية ام شيعية؟"، فبعد تمعنه بها وقر اءتها أجاب "صحيح افهم انها إسلامية فقط"، و عندما وصلت بعض من اعداد المجلة الى الأستاذ الدكتور احمد مطلوب رئيس المجمع العلمي 
العر اقي، كتب شكر للمجلة ولكادر هـا واكد " ان البلد محتاج لإصدار مجلة قرآنية بهذا المستوى، وأتمنى ان تمد جناحيها على الوطن الاسلامي"، وعرض نفسه ليكون عضوا ضمن الهياة الاستتـارية للمجلة، كما وردت

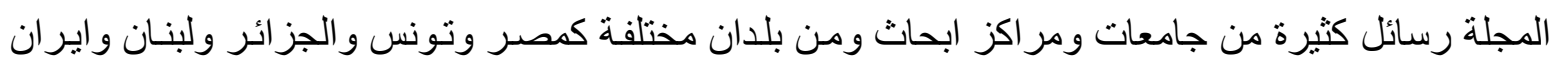

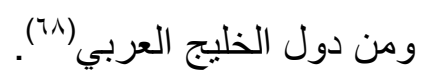
جاء كل هذا القبول الواسع للمجلة جر اء انتظام أوقات صدور ها، وتوازن طروحاتها وابتعادهـا عن التطرف والتحريف والتعصب، وان اهتمامها منصب على طرح أفكار التسـامح والتقارب التي يؤكد عليها القران الكريم، و انبياء الله ورسله، وتأكيداً لكلامنا هو نشر ها لأبحاث كبار الاساتذة والباحثين و المهتمين بعلوم القران ومن مختلف المذاهب الاسـلامية. عززت النقاط الانفة الذكر دور مجلـة المصباح في عملية النشـر

$$
\text { الاكاديمي داخل العراق وخارجه. }
$$

و هذا الجهد المتميز يقوم به ويشرف عليه ويقومـه شخصـان لا غيرهـا رئيس التحرير ومدير التحرير، اللهم الا ما تفرضه الأبحـاث المطلوبـة للترقيـة العلميـة الجامعيـة من وجوب عرضـهـا على خبر اء الاختصـاص لتقويمها ومنحها الموافقة على صلاحية النشر، فجميع البحوث لم تتشر كما وردت من كاتبيها بل يجري عليها القلم ويعدل ويثبت ويضيف ولم يسلم حتى العنوان في بعض الأحيان ليستبدل بمـا هو اكثر ملائمسة لجوهر الموضوع ان اقتضت الحاجة الى ذلك التبديل و التغير.
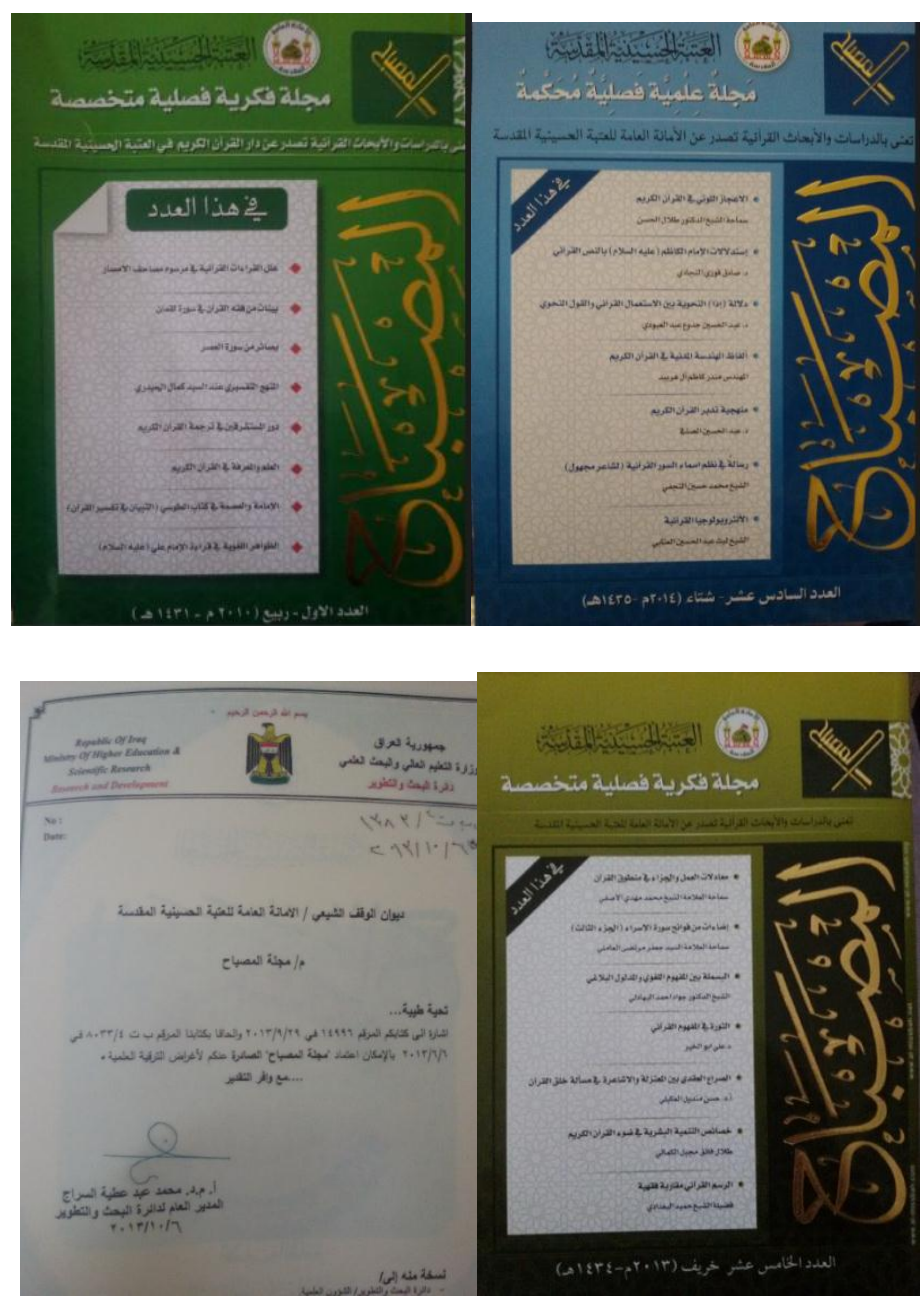


\section{ب - مجلة دواة المحكمة:}

مجلة فصلية محكمة، تعنى بالبحوث و الدراسات اللغوية والتربوية الهادفة لرفع الو اقع الفكري و المعرفي للمجتمع، تصدر عن دار اللغة العربية في العتبة الحسينية المقدسة، بإنشر اف سماحة الثيخ الكربلائي، ورئيس تحرير ها الأستاذ لطيف القصاب، ومدير تحرير ها الأستاذ المسـاعد الدكتور خالد عباس السياب. و الهدف من بن إصدار ها كما جاء على لسان هياة التحرير" لغتنا اداتتا الكبرى وبـ(دو اتنا) نسطر ها اقو الاً وابحاثتاً ودر اسـات لتصل الى العـالم معبرة عن هويتتا ومواجهة تحديات العصر الجديدة، لعل من أهمها التحديات المعلوماتيـة و التقنية و الثقافية و الطارئة. ان الحفاظ على لغتنا يعني الحفاظ على هويتنا، وهذا يكاد ان يكون فرضـاً دينياً في

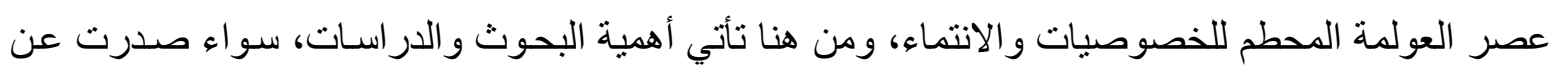

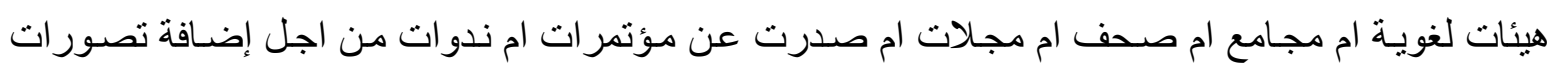

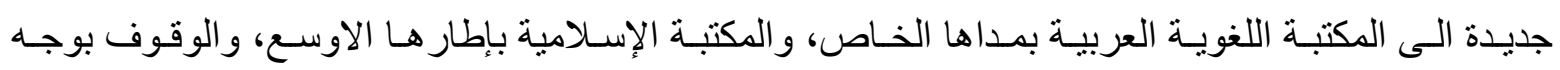

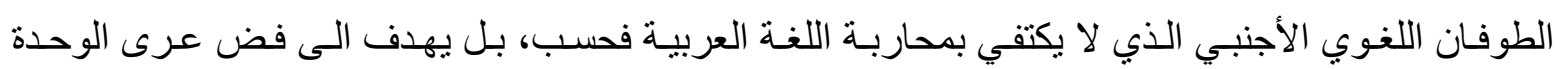

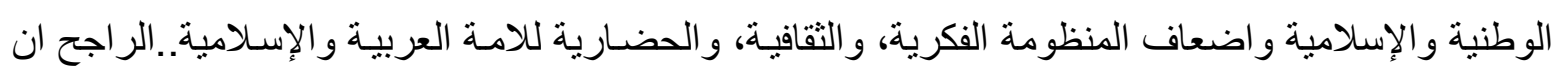
محاولة النيل من لغتنا بكل السبل و الاشكال تستند الى تخطيط سياسي استر اتيجي وان اتخذت طابعاً ثقافياً اجتماعيا ولا ينبغي ان ينظر اليه بوصفه اسلوباً عفوياً او فطرياً او طبيعياً"(79).

تتألف هياتهـا الاستشـارية و التحريريـة مـن مجموعـة مـن الأسـاتذة الاكفـاء والمختصسين باللغـة العربيـة

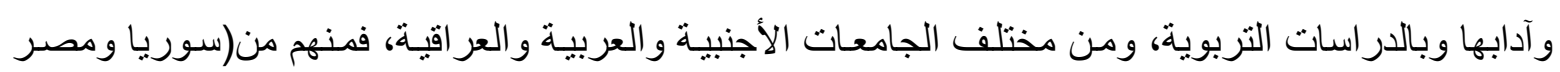

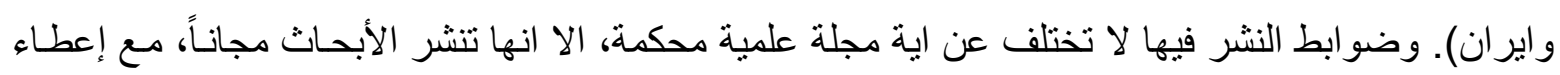
مكافاة مالية مجزية للباحث مع عدد من المجلة. وقد حصلت المجلة على اعتمـاد التحكيم العلمي من وزارة

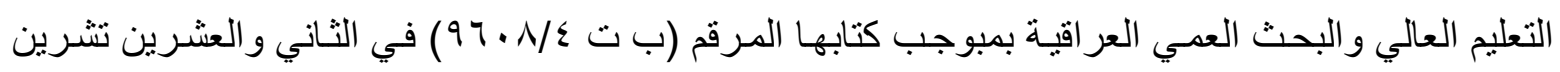

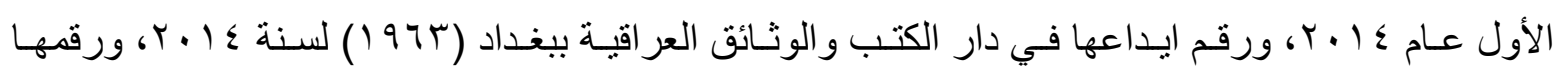
الدولي هو ISSN:2411-5711 ، صدر العدد الأول (التجريبي أب قبل استحصـالها على التحكيم العلمي)

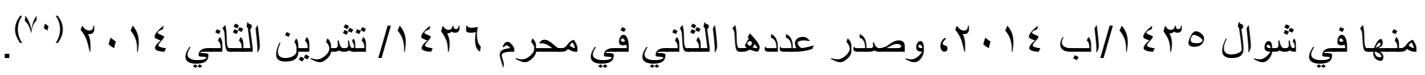

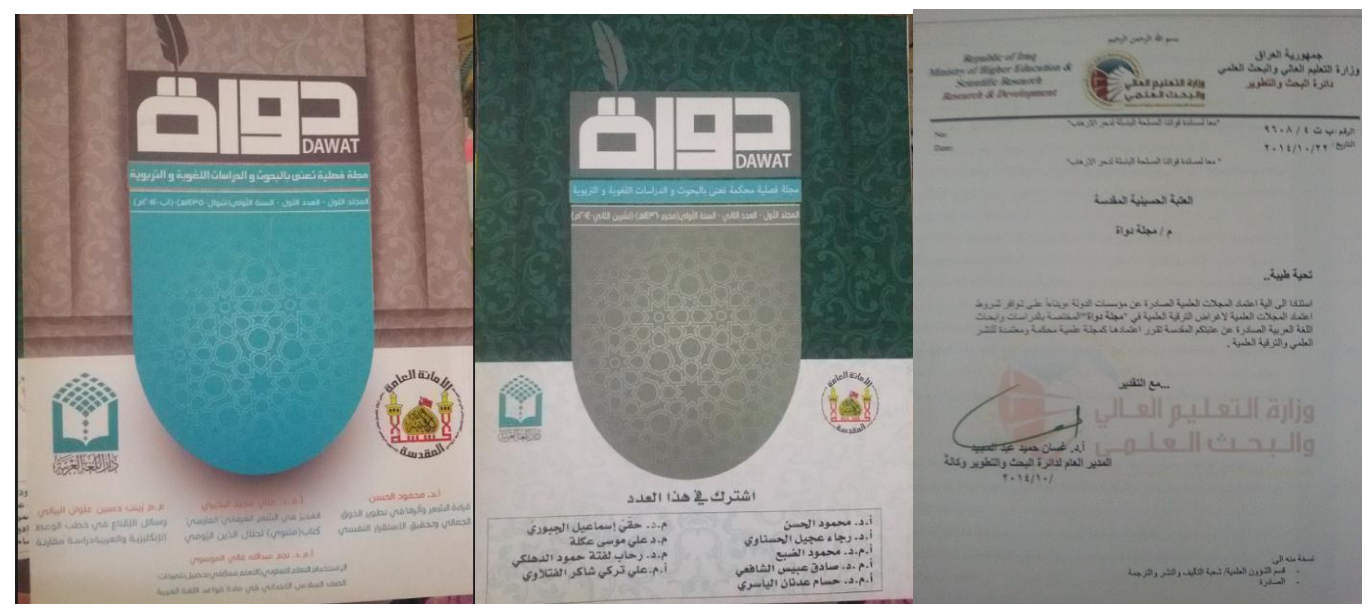




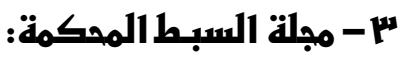

مجلة علمية فصلية محكمة، تُعنى بنشر الإرث الحضاري والثقافي لمدينـة كربلاء المقدسة، تصدر عن

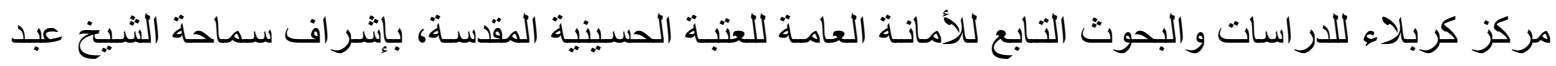

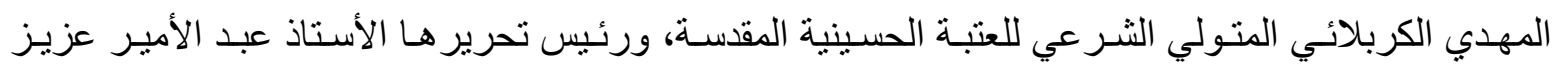
القريشي مدير المركز، ومدير تحرير ها الأستاذ الدكتور رياض كاظم سلمان الجميلي. وسبب إصدار ها حسب القائمين عليها هو لإيمان إدارة العتبة الحسينية المقدسة ومركز كربلاء للار اسـات و البحوث بالأهمية التاريخية التي تحظى بها مدينة كربلاء المقدسة لما تحمله من ارث ديني وثقافي وحضساري على صعيد الحيـاة الفكريـة و العلمية، وجاءت تسميتها بالسبط تيمناً بالإمام الحسين (ع) لقول رسول الله(ص) فيه(حسين سبط من الاسباط) و هي تتطلق من مدينة كربلاء لتلبي الاحتياجات المستجدة في المجتمع وتسهم بقدر مناسب في حفظ هويـة هذه المدينة التي غُيبت لعقود من الزمن.

كمـا اكد القـائمين على المجلـة ان احد اهم الأسباب لإصـدار ها هـو" وخـلال تتبعنـا للمجـلات العلميـة

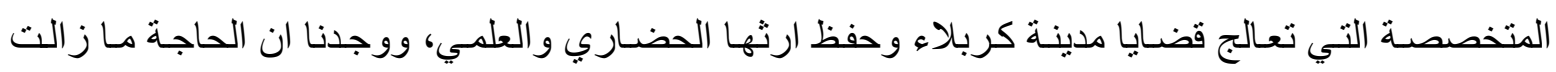
قائمة لوجود مجلة تخصصية تأخذ على عاتقها دراسة هذا الإرث الكبير حتى وان تعددت الإصدار ات العلى العيـة في ذلك، لان المدينة تستحق منا الكثير لفتح قنوات المعرفة العلمية لتغطيته، الامر الذي جعلنـا امسام مسؤولية علمية وتاريخية للإسراع في اصدار العدد الأول من هذه المجلة لرفد الباحثين و المفكرين بدر اسـات تخصصية

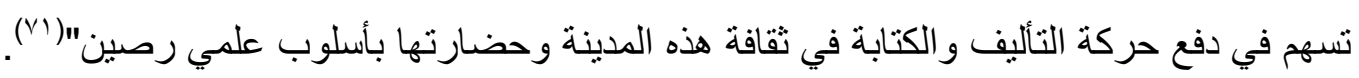
تستقبل المجلة البحوث و الدر اسات في مختلف الاختصاصات الإنسانية (اللغة العربية وآدابها، التاريخ،

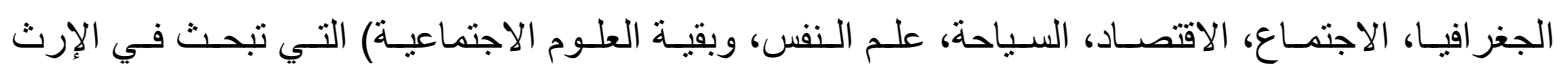

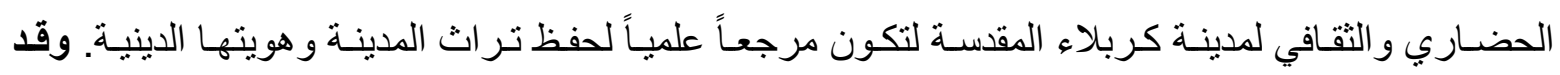
حصلت مجلة السبط على اعتماد التحكيم العلمي من قبل وزارة التعليم العالي والبحث العدي العر اقيـة بمبوجب

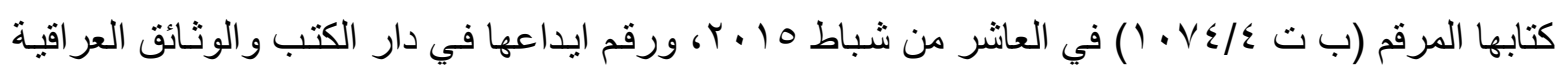

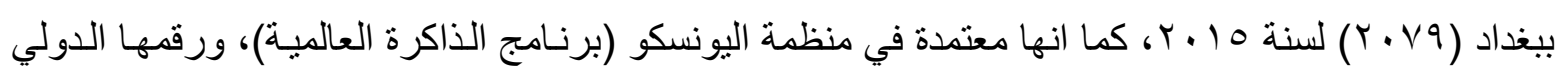

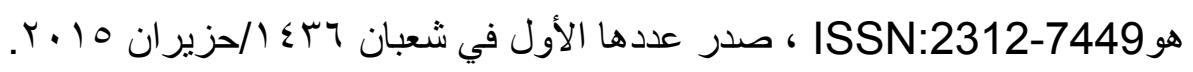

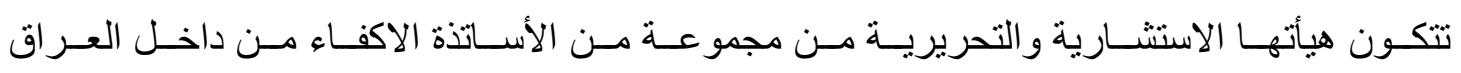
وخارجه(فرنسا، لبنان، اليمن، عمان)، اما تعليمات النشر فيها لا تختلف عن أي مجلة علميـة محكمة، الا انها

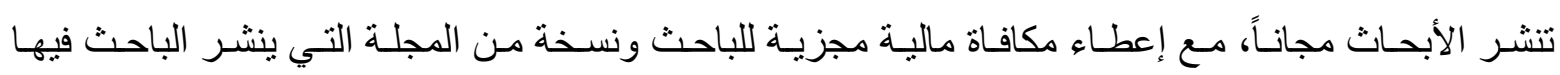
بحثه(Yr). وقد نالت المجلة استحسان ومقبولية الكثير من الأسـاتذة الجامعيين و القر اءو والمهتمين بتاريخ المدن

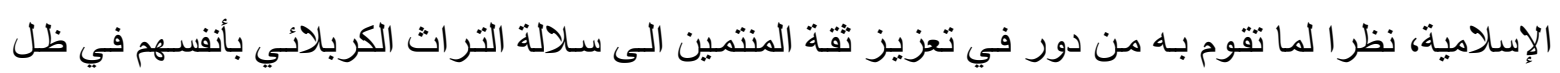

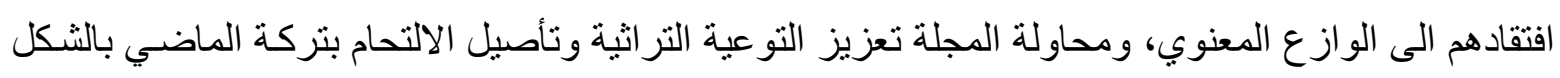

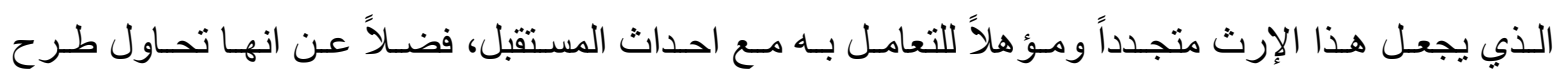


موضو عات تعزز التنمية بأبعادها المتتوعـة: الفكريـة والاقتصـادية ومـا الى ذلك، فالكثف عن التراث يعزز السياحة، ويقوي العائدات.

كما وردت للمجلة الكثير من الرسـائل الخطية او عبر بريدها الاليكتروني من داخل العراق وخارجـه

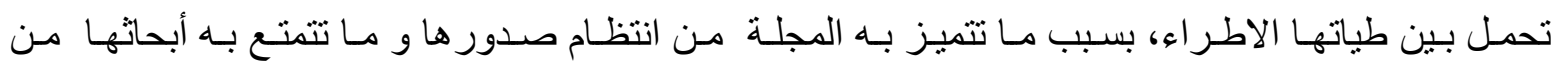

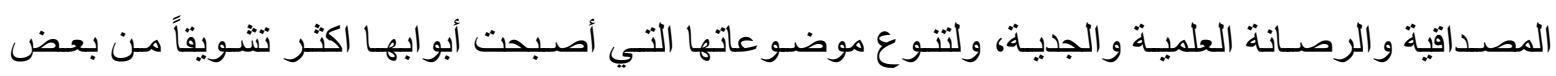

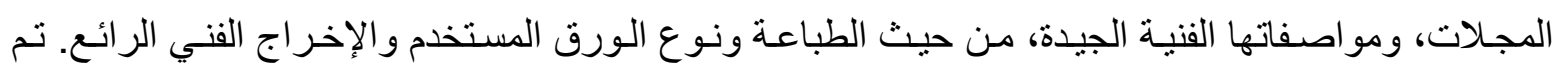

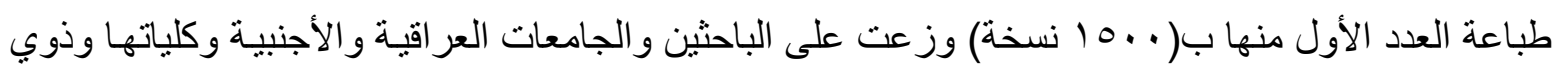

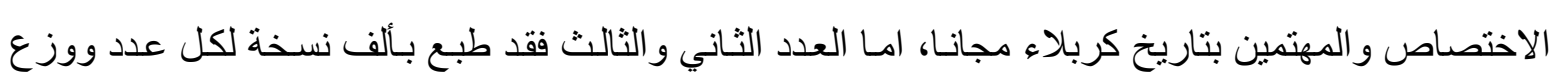
مجانا ايضاً.

اما دور مجلة السبط المحكمة في النشر الاكاديمي يتمثل في تشجيع الباحثين في الكتابة في موضو عاتها

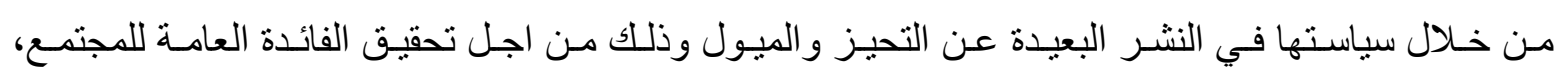

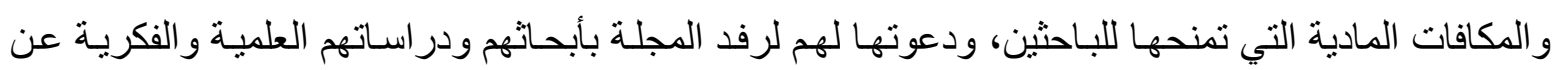

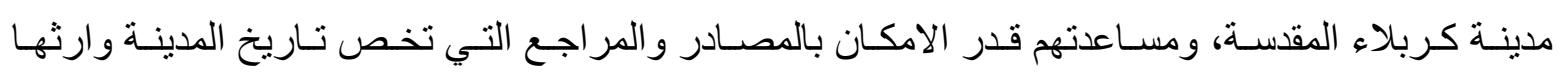
الحضاري، كما ان المجلة تصل الى ابعد المديات من خلال تميز ها بطباعـة وإخر اج ممتاز ، وحرص القائمين

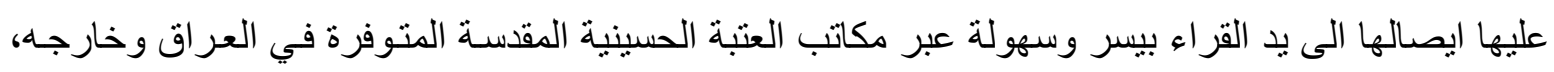
كما انها توزع في اغلب المؤتمرات و الندوات و الورش التي يقيمها المركز.

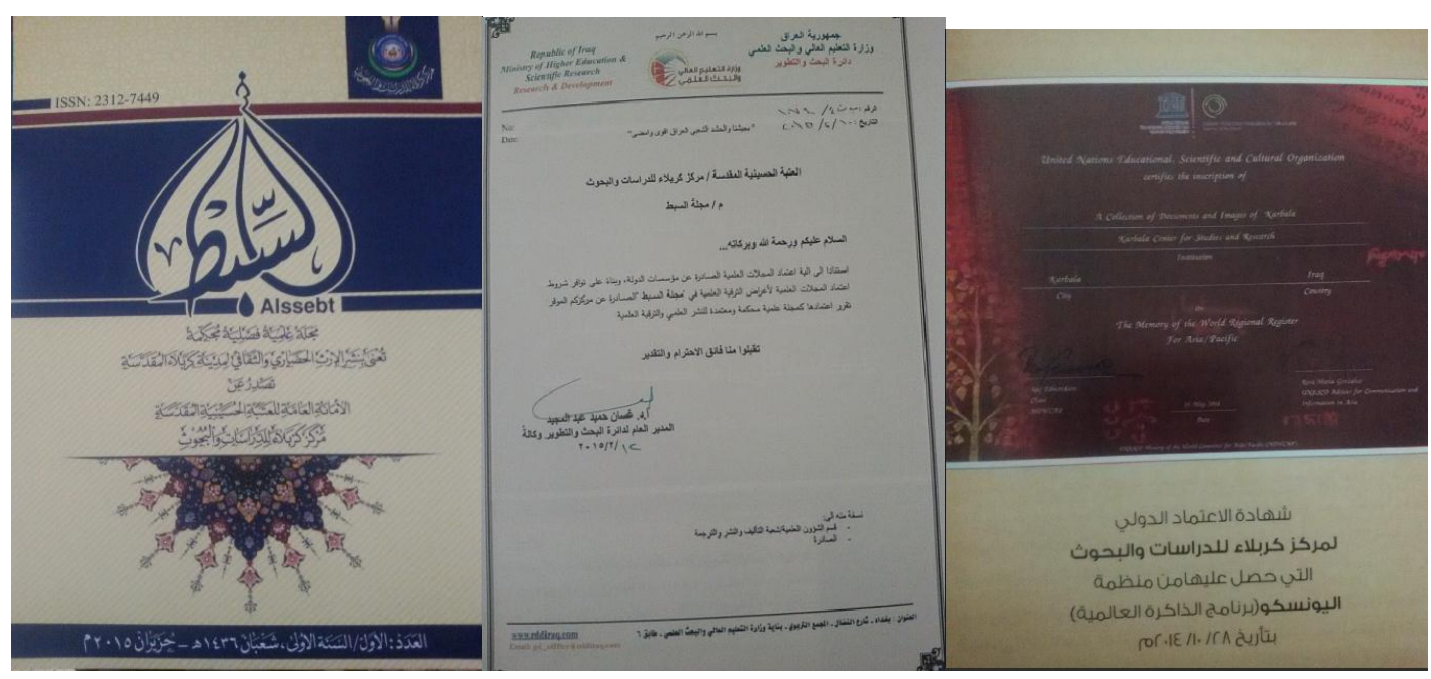

\section{ع - مجلة الهبيزن:}

مجلة فصلية محكمة، تعنى بعلوم كتاب نهج البلاغـة وبسيرة الامسام علي وفكره، تصدر عن مؤسسـة علوم نهج البلاغة في العتبة الحسينية المقدسة، بإثر اف سماحة الثيخ عبد المهدي الكربلائي المتولي الثرعي

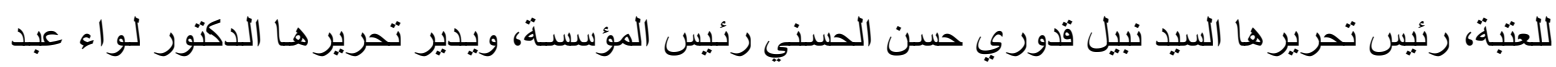
الحسن عطية، و المجلة مجازة من قبل وزارة التعليم العالي والبحث العلمي العر اقية. 
ان لكل امة من الأمم حضارتها التي تفتخر بها على غبر ها من الأمم، ولكل حضارة رجالها الذين بنوهـا

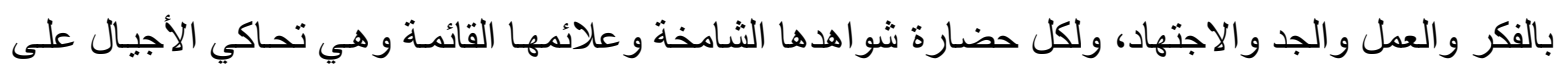
كرور الأيام ان هاهنا كانت امـة. لكنتـا هنـا في حضـارة ليست كبقيـة الحضـار ات فثـموخها قائمسة في الاذهـان

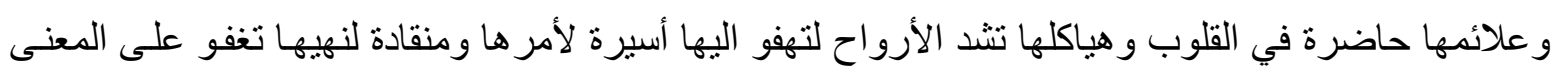

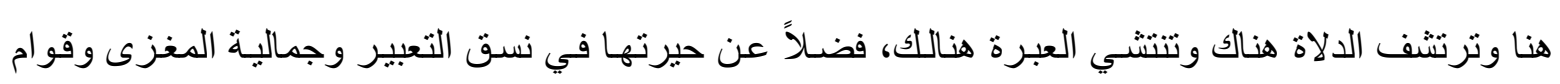

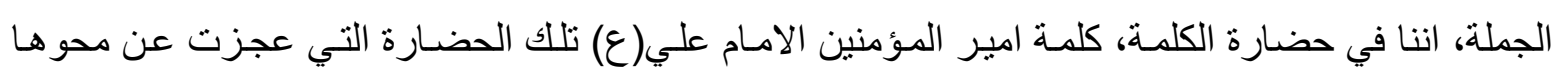

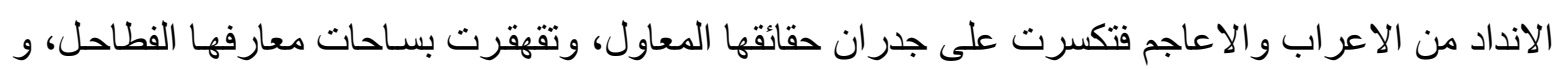

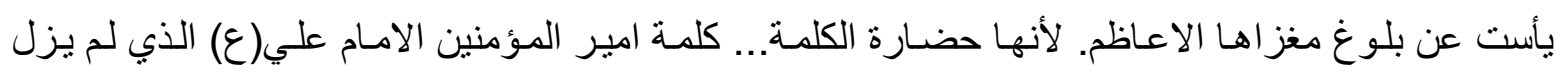

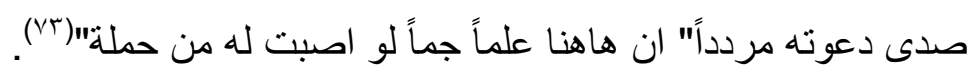
من هنا اتخذت مؤسسة علوم نهج البلاغة منهجها في النهوض بهذا التراث المعرفي الذي اكتنزه كتاب نهج البلاغة، فقامت بتأسيس مجلة علمية محكمة معتمدة لأغر اض الترقية العلمية في المجال الاكاديمي، تهدف الى استنهاض الأقلام العلمية والفكرية للارتشاف من معين علوم الامام علي (ع) وكتاب نهج البلاغة الذي يعد

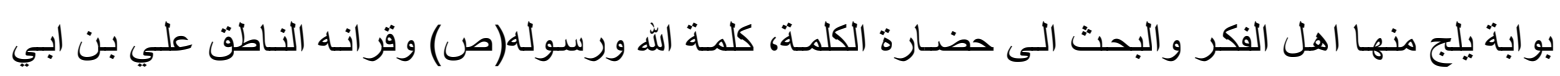

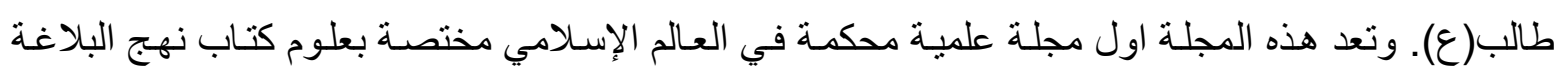

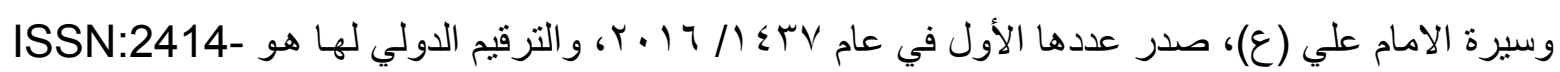

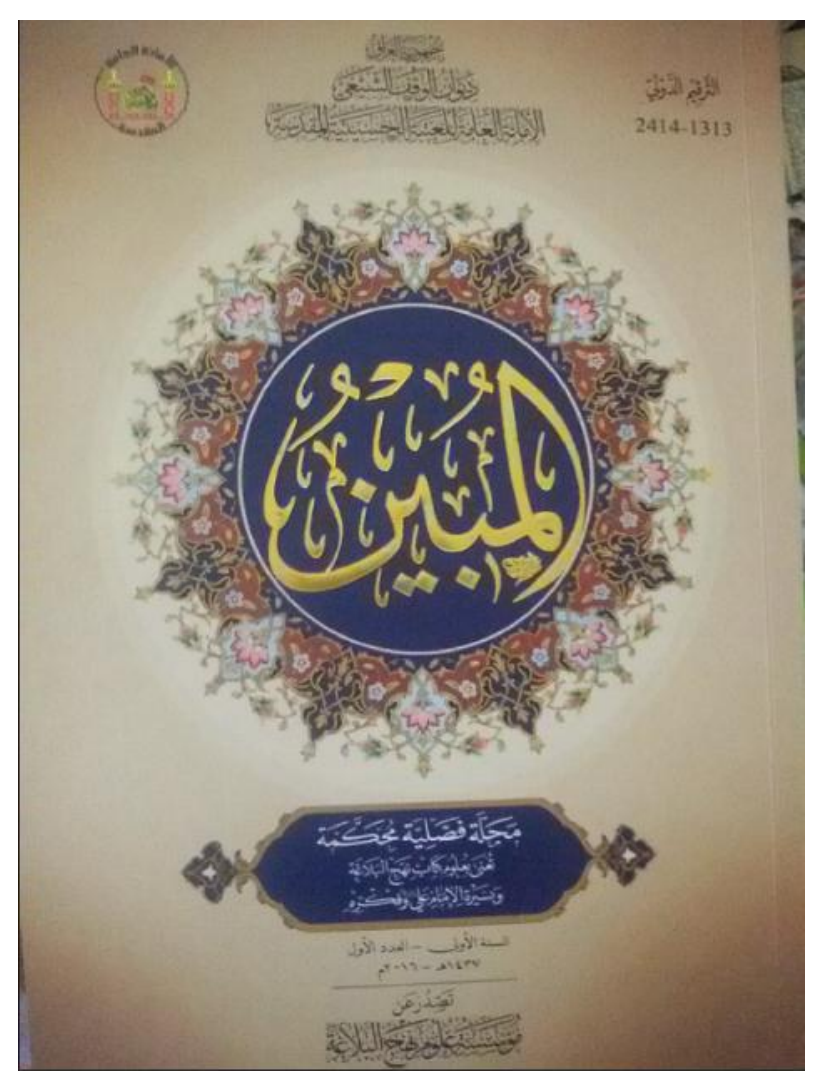




\section{المبمث الثالث: دور هجلات العتبة العباسية المكمة في النشر الاكاديمي:}

1- مجلة العمبد المهكمة:

مجلة فصلية محكمة، تعنى بالأبحاث و الدراسات الإنسـانية، تصدر عن مركز العميد الدولي في العتبـة العباسية المقدسة، ومجـازة من قبل وزارة التعليم العالي والبحث العلمي، ومعتمدة لأغر اض الترقيـة العلميـة

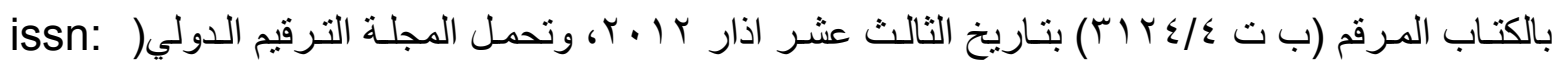

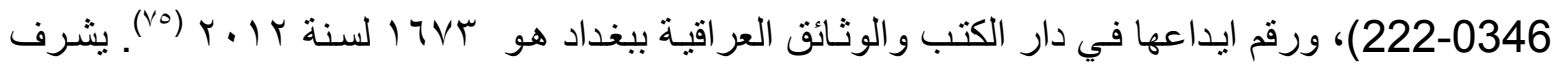
السيد احمد الصافي المتولي الثرعي للعتبـة العباسية المقدسة على هذه المجلة، ويتر اس تحرير هـا السبد ليث الموسوي ولها هيئة استشارية مؤلفة من أ.د طارق عبد عون الجنابي، وأ.د رياض طلارق العميدي، وأ.د كريم

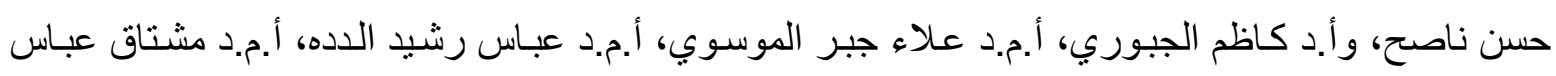

اما كادر المجلة فبإدارة التحرير د. سرحان جفات من (جامعة القادسية)، وسكرتير التحرير رضوان

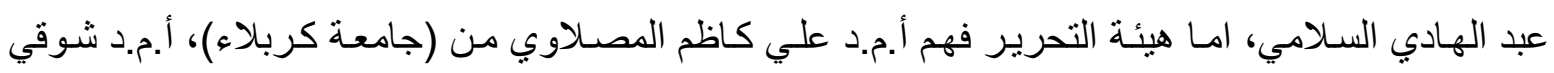
مصطفى الموسوي من جامعة بابل، أ.م.د حيدر غازي الموسوي من جامعة بابل، امسا التدقيق اللغوي فهم د. علي كاظم علي المدني ، ود. شعلان عبد علي سلطان.

اما الهذف من إصدار ها فعلى حد قول السيد الصافي المشرف على المجلة ان صدور ها جاء بما يتناسب الحياة اليومية بالقول" لا شك ان الجانب المعرفي في حياتنا يمثل الركيزة الأسـاس في حياة الثـعوب ونمائها المتواصل، و الثُعب الذي يقرا هو الثُعب الذي لا يموت، و الثَعب الجاهل هو الثـعب الميت، والعراق بلد

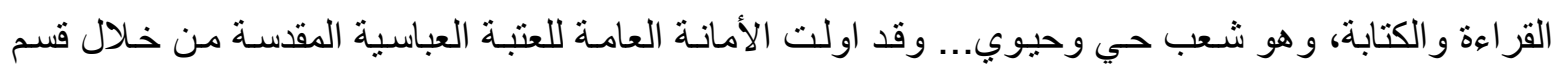

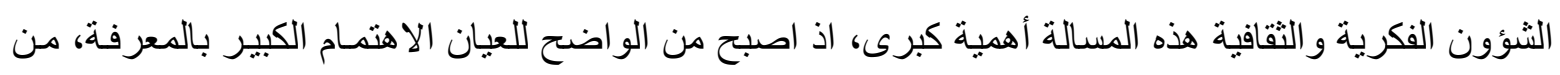

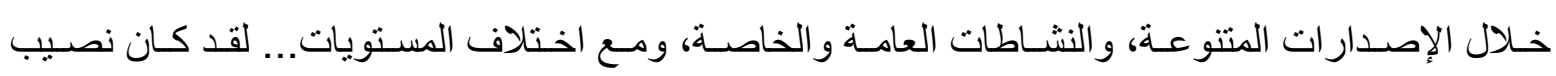

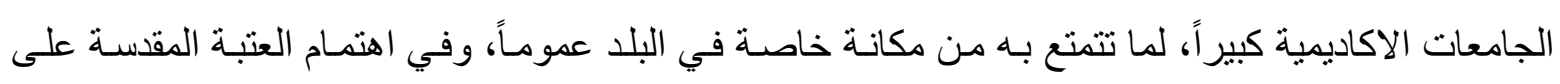

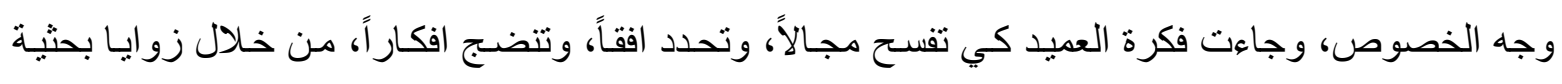

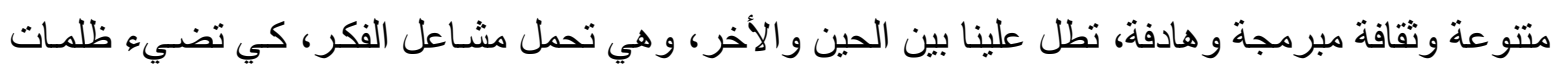

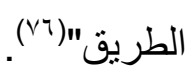

اما السيد ليث الموسوي رئيس تحرير المجلة فتطرق الى أسباب التسمية واهميـة المجلة بقولـه" لمـا كـان الاعتقـاد بوجود فيض متز احم من البحوث و الدر اسـات الإنسـانية و عظيم نفعها، تبنت الأمانـة العامـة للعتبـة

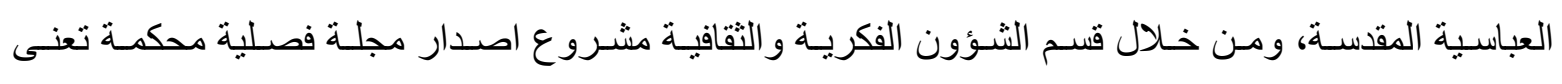
بالدر اسات و البحوث الإنسانية، وسميت بـ(العميد) تيمناً بلقب صاحب المرقد الثريف ابي الفضل العباس(ع)،

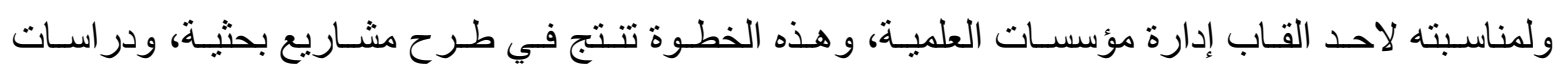

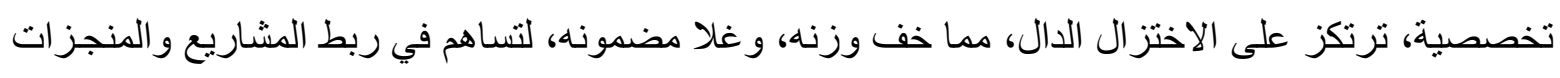


الفكرية، و الكثف عن خلفياتها او تفسير ها، واستكثاف مسـار اتها التكوينيةـ لتكون بحق- عنصر اغنـاء لرواد العلم و المعرفة، ومن يريد ارتقاء سلم العلوم التخصصية"'(VV). ضو ابط النشر فيها لا تختلف عن ايـة مجلة علمية محكمـة، الا انها تتشر الأبحاث مجاناً، مع إعطاء مكافاة مالية مجزية للباحث، ونسخة من المجلة المنشور فيها البحث.

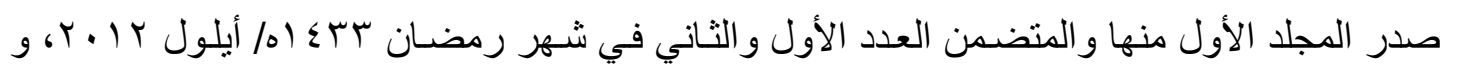
قد سبقها العدد صفر الذي صدر قبـل استحصـال التحكيم العلمي مـن وزارة التعليم العسالي والبحث العلمي

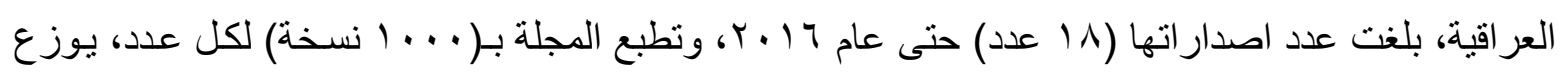
قسم منها مجانا على الباحثين و الجامعات العر اقيـة والأجنبيـة وكلياتها ومكتباتها وذوي الاختصساص و المرتمين

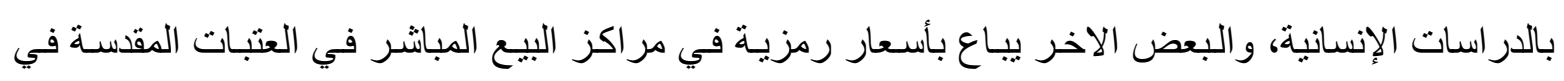
العر اق وفي معارضها الدائمة.

نالـت مجلـة العميـد المحكمـة استحســان ومقبوليـة الكثيـر مسن الأسـاتذة الجـامعيين والقـر اءو والمهتمـين

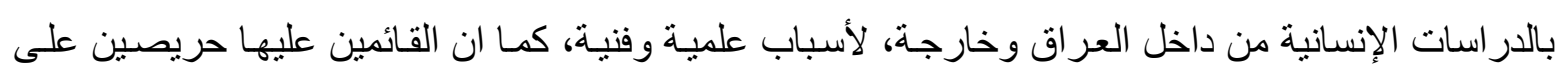

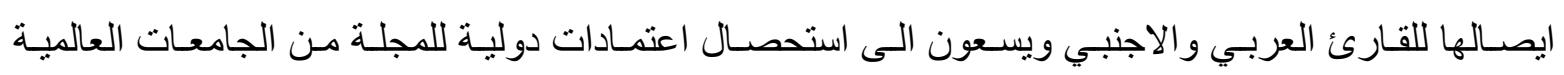
ومعامل تأثير(impact factor) الذي يعكس جودة المجلة(V^).

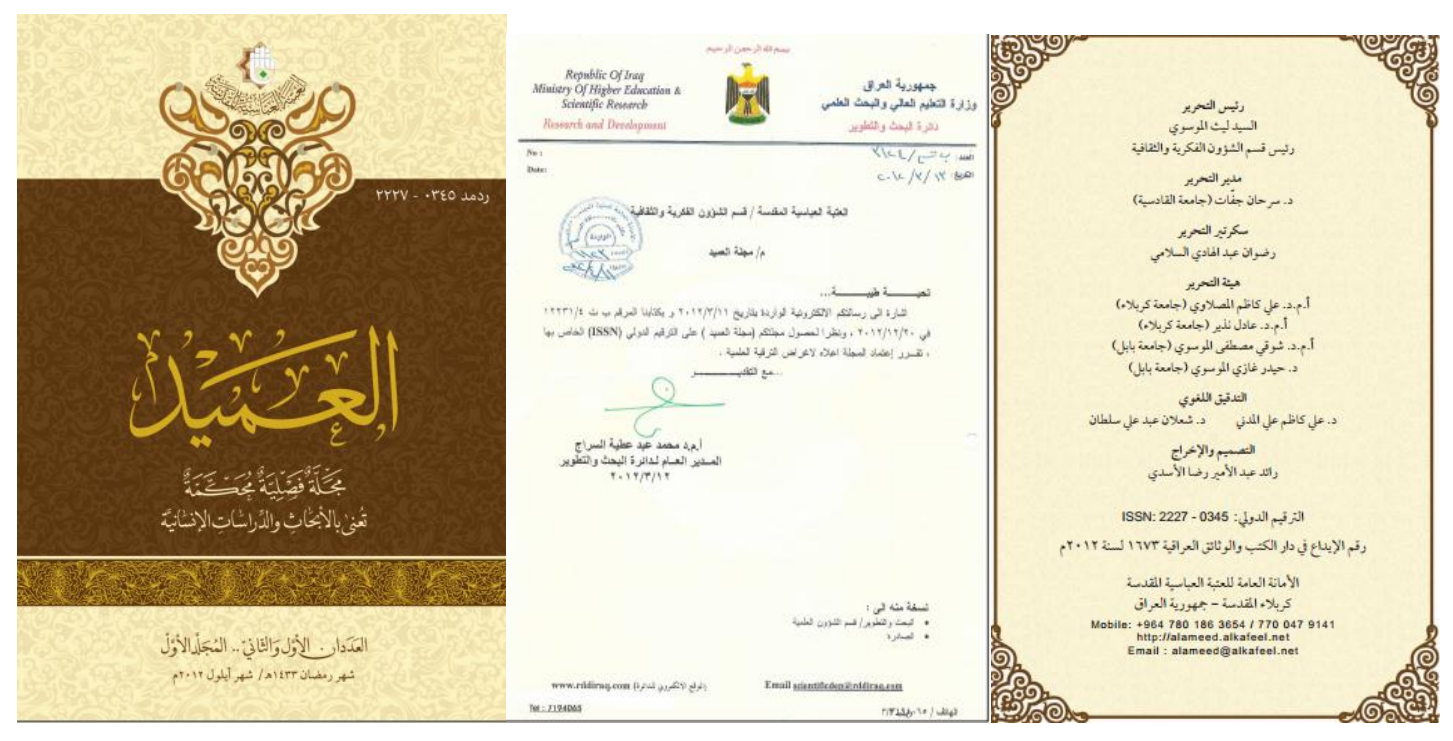

\section{r مجلة تراث كربلاء المحكمة:}

مجلة فصلية محكمة، تعنى بالتراث الكربلائي، تصدر عن مركز تر اث كربلاء- قسم الثؤون الفكريـة و الثقافية في العتبة العباسية المقدسة، بإنـر اف السيد احمد الصـافي المتولي الثـرعي للعتبـة العباسية المقدسـة، ورئيس تحرير ها الدكتور احسان علي سعيد الغريفي، ومدير تحرير ها الأستاذ الدكتور مشتاق عباس معن (جامعة بغداد- كلية التربية ابن رشد). وتتكون هياتها الاستشارية والتحريرية من مجموعة من الأساتذة الاكفاء

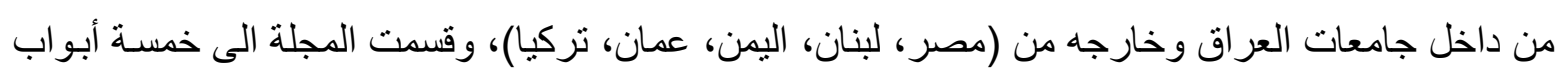

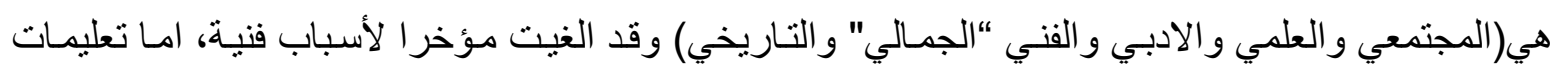


النشر فيها لا تختلف عن أي مجلة علمية محكمة، الا انها تنشر الأبحاث مجاناً، مع إعطاء مكافاة ماليـة مجزيـة للباحث و عدد من المجلة التي ينشر فيه الباحث بحثث.

و عند سؤالنا عن سبب اصدار المجلة وسط زحام المجلات التي تعنى بالدر اسات الإنسانية، فكانت إجابـة الدكتور احسان الغريفي رئيس تحريرها " ان المجتمعات الراقية تولي وسائل البحث العلمي و التجريبي اهتمامـاً

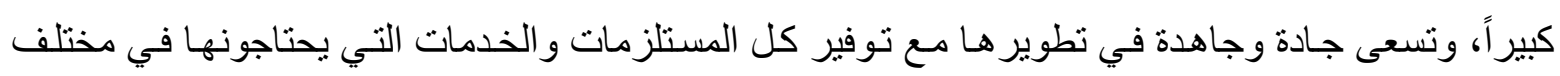
الدر اسات و البحوث، مما أدى الى استمرارية التقدم العلمي في تللك المجتمعات، وكان احد الأسباب الفاعلـة في رقيها، و لأجل المساهمة في نشـر المعـارف التراثية والحضـارية واحياء تراث مدينـة الامـام الحسين(ع) الذي يشكل ذاكرة الامـة وتاريخها الحضـاري و الثقافي الذي تأترت بـه جميع الحضـار ات الإنسانية بصـورة عامهة،

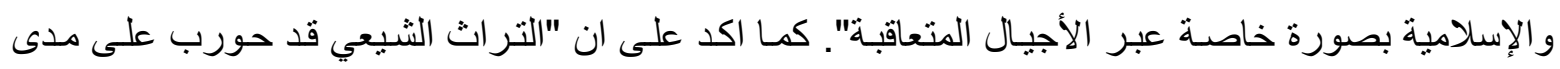
عهود كثيرة، وتعرض الى إبادة ثقافية، اما اليوم فانه يمر بعصره الذهبي، و على المؤسسـات الثيعية استغلال

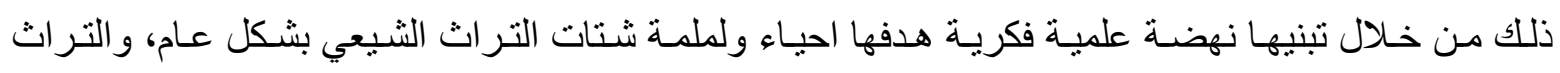
الكربلائي بشكل خاص، و عليهم تبريز دور علماء الثيعة قدر الامكان بعد ان تعرضوا الى اضطهاد السلطة الحاكمة"(va).

ووجدنا ضالتنا أيضا في كلمات الهياتين الاستشارية والتحريرية للإجابة عن سبب اصدار مجلة علميـة محكمة تهتم بكربلاء وتر اثها، فكانت الإجابة "... ان كربلاء لا تمثل رقعة جغر افية تحدها حدود مكانية ماديـة

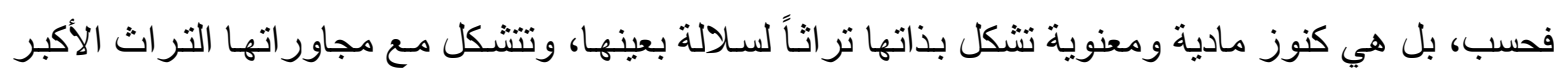
لسلالة أوسع تنتمي اليها أي: العراق، والثرق، وبهذا التراتب تتضـاعف مستويات الحيف التي وقعت عليها:

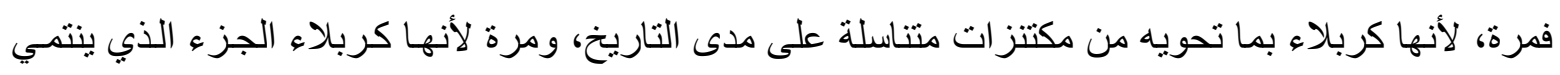

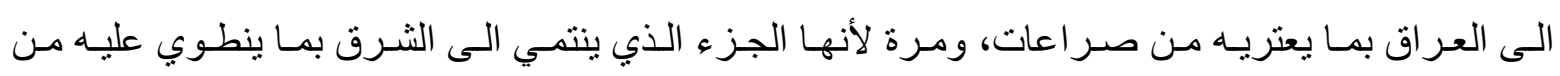
استهدافات، فكل مستوى من هذه المستويات اضفى طبقة من الحيف على تر اثها، حتى غُيبت وغُيب تر اثها،

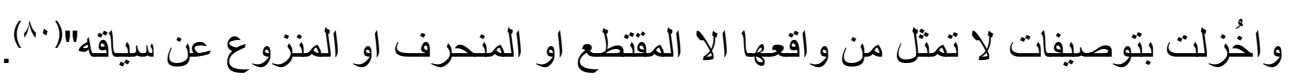

وبناءً على ما تقدم تصدى مركز تر اث كربلاء التابع للعتبـة العباسية المقسـة الى تأسيس مجلـة علميـة

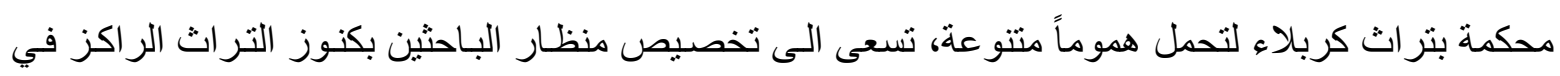

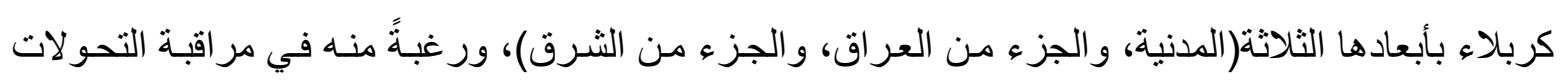

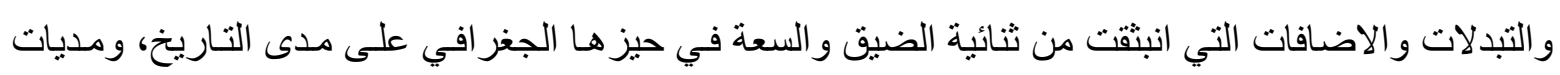
تعالقها مع مجاور اتها، وانعكاس تلك العلاقة سلباً او ايجاباً على حر اكها الثقافي و المعرفي.

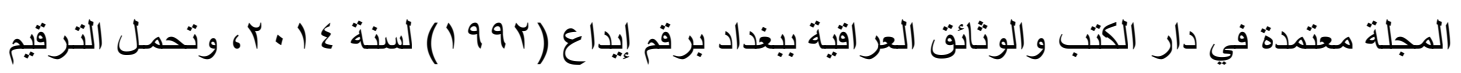

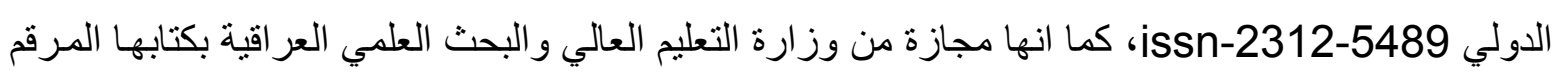

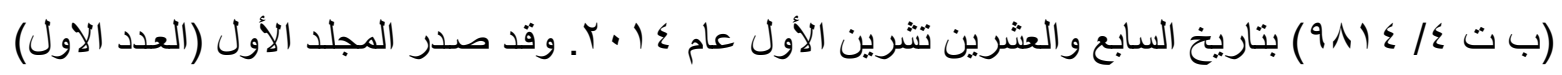

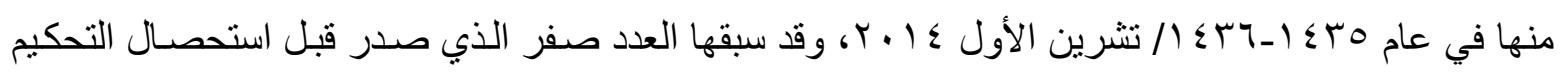

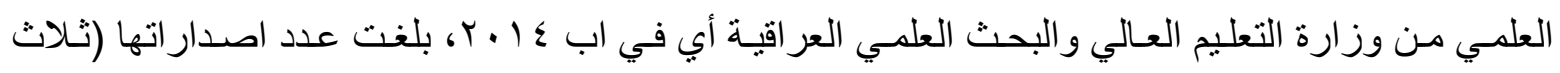




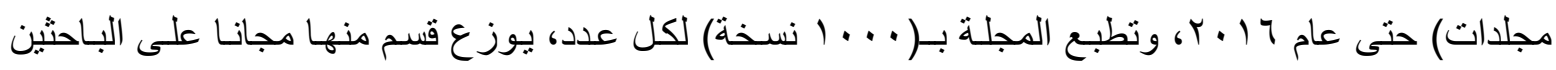

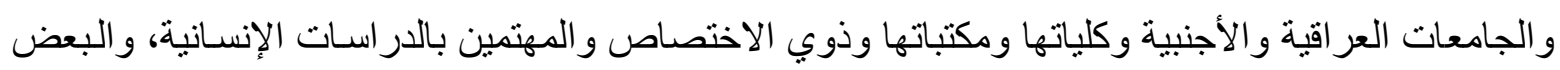

الاخر يباع بأسعار رمزية في مر اكز البيع المباشر في العتبات المقسة في العراق وفي معارضها الدائمة( الان. و لأجل دعم التوثيق التر اثي لمدينة كربلاء و احباء تر اثها الفكري و الثقافي المشرف و المؤثر في نواحي الحياة المختلفة، ولتشـيع البـاحثين و الكتاب على الكتابـة عن تر اث هذه المدينـة الر ائدة، اعلن مركز تر تراث كربلاء ومجلة تراث كربلاء في أواسط العام 0 ـ ب عن مسابقة افضل مؤلف عن تراث كربلاء، ومسـابقة السـاقي للأبحاث الاكاديميـة، ويمنح الفائزين جوائز ماليـة من (^ ملايين دينار عر اقي الى بـ ملايين دينار

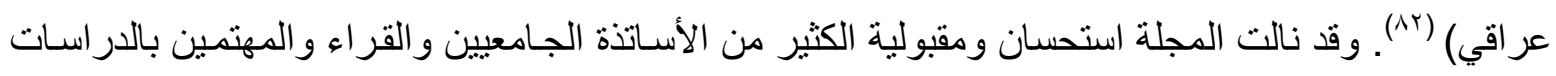

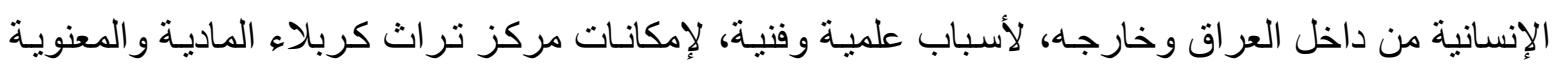

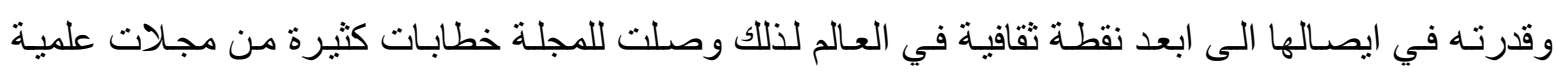

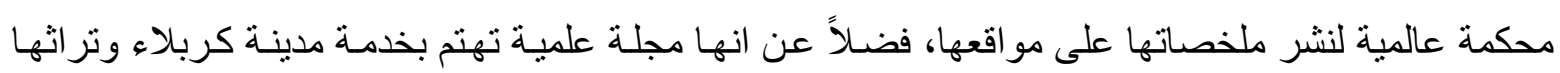

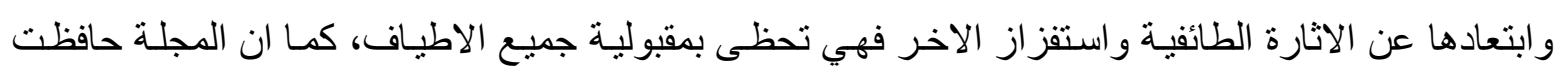
على شكل غلافها الخارجي وجودة الطباعة و التنظيم.
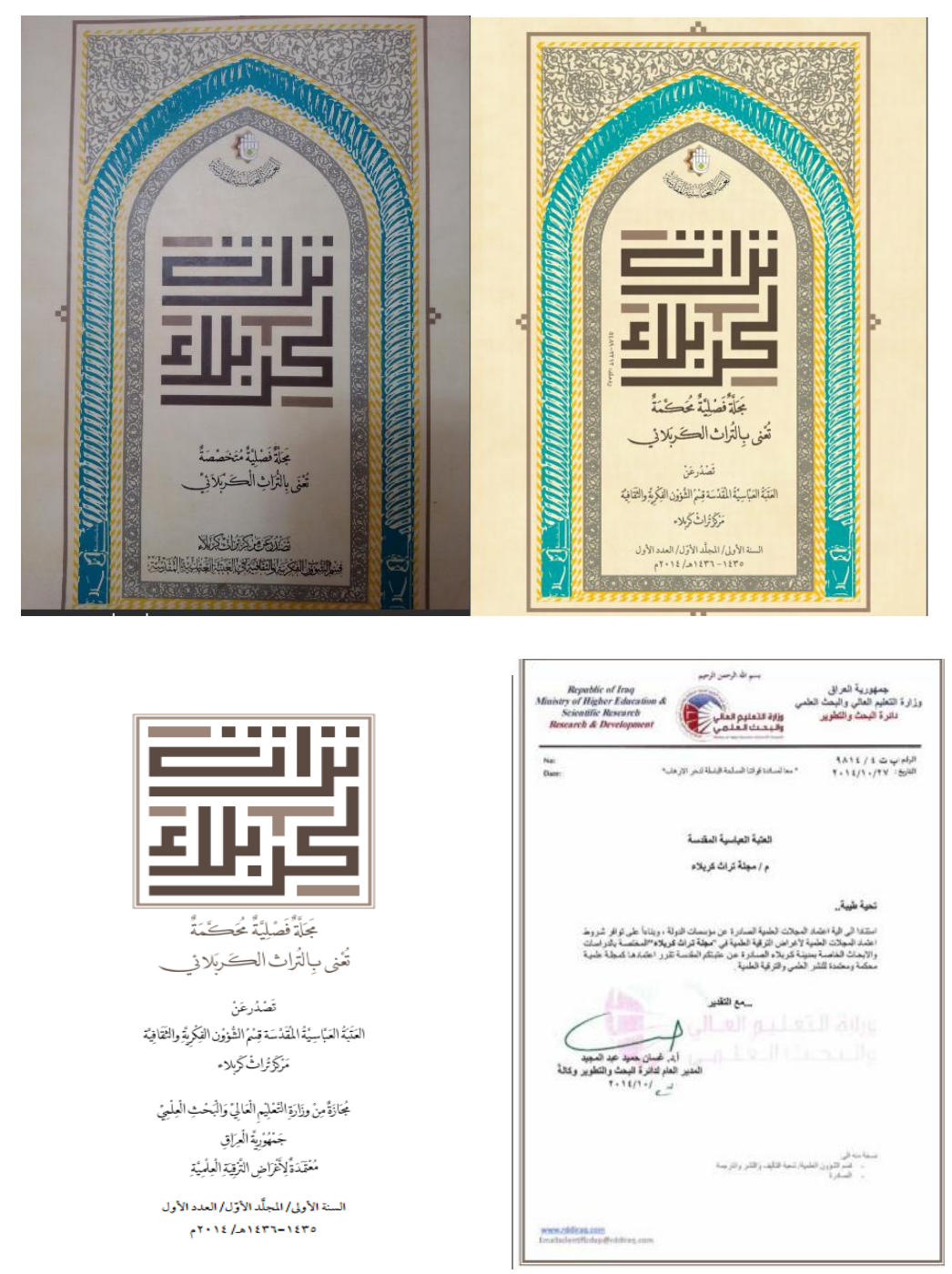

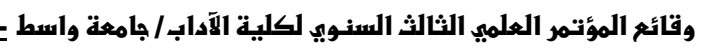




\section{"1" - مجلة الباهر المحكمة:}

مجلة علميـة محكمة، تعنى بالأبحاث والدر اسـات العلميـة أبي انها تختص بـالعلوم الطبيعيـة والهندسية،

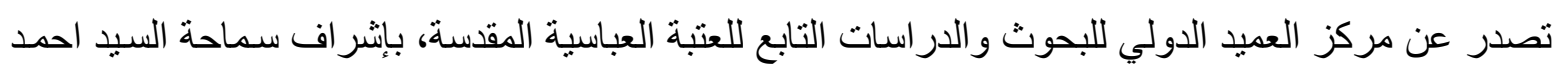

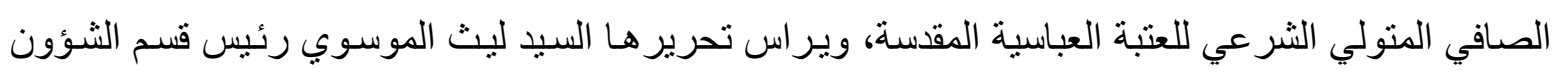
الفكرية والثقافية، ويدير تحرير ها الأستاذ المساعد الدكتور نورس محمد شهيد الدهان (جامعة كربلاء- كلية العلوم). و الهوف من اصدار هذه المجلة هو"... فهذا مشروع معرفي اخر تزفه العتبـة العباسية المقدسة الى ولى

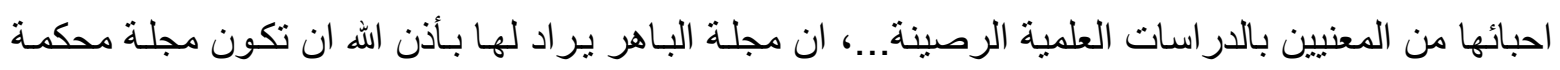

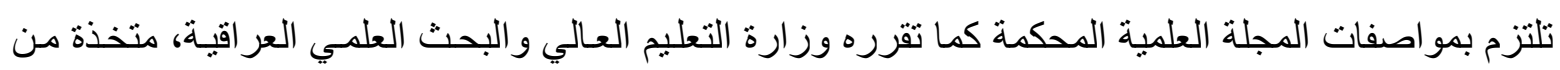

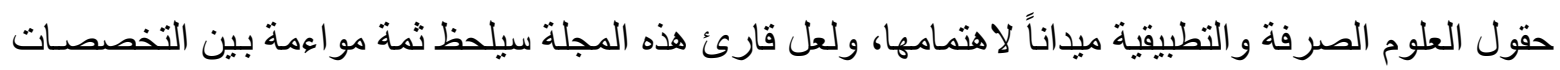

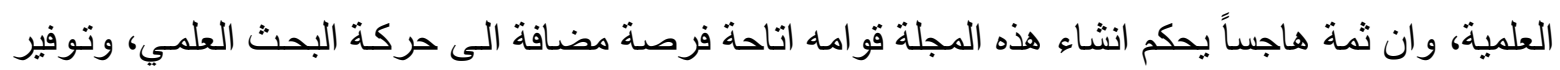
سبل جديدة لالتئام شمل الدارسين المتحلقين حول صحف البحث، وسبل الدرس". اما سبب تسميتها بالباهر فيعود الى" ان المجلة اتخذت من أسماء سيدنا ابي الفضل العباس بن امير

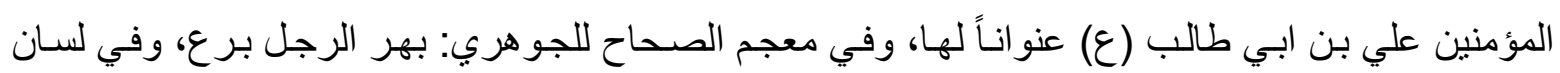

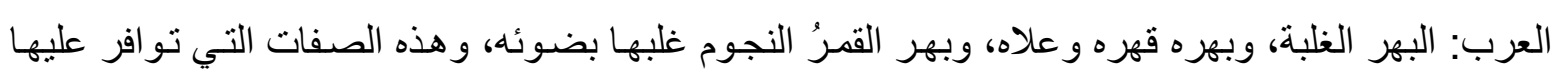
سيدنا العباس (ع) سوف تكون مثابة لباحثي هذه المجلة وخدمتها الساعين الى البر اعة العلمية و التفوق البحثي، وهن وهنه

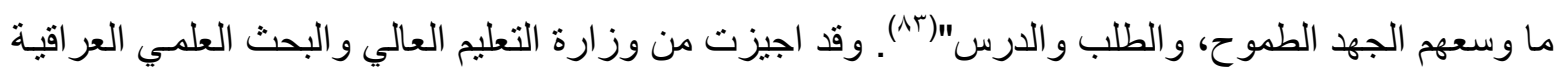

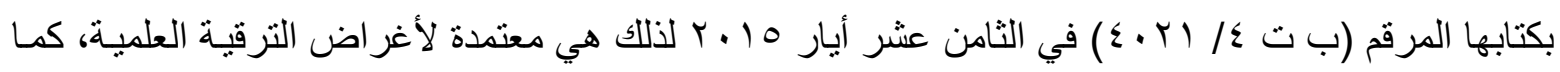

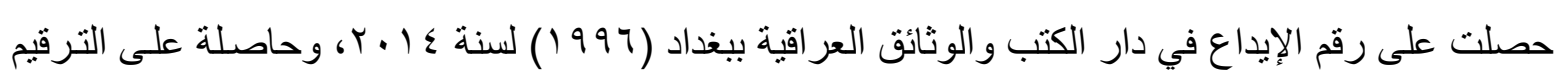
ISSN-2312-5721 داخل جامعات العر اق وخارجه من (الو لايات المتحدة الامريكية)، كما ان ضوابط النشر فيها لا تختلف عن ايـة وله

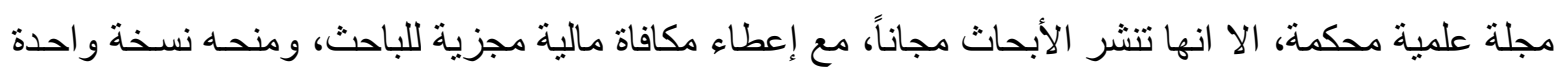

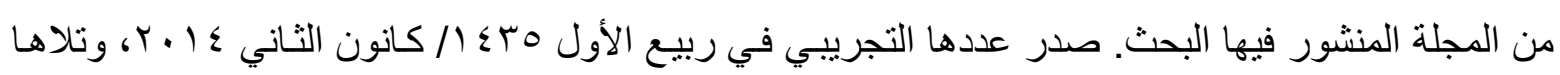

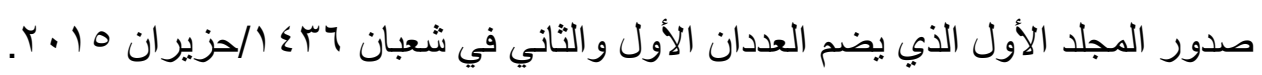
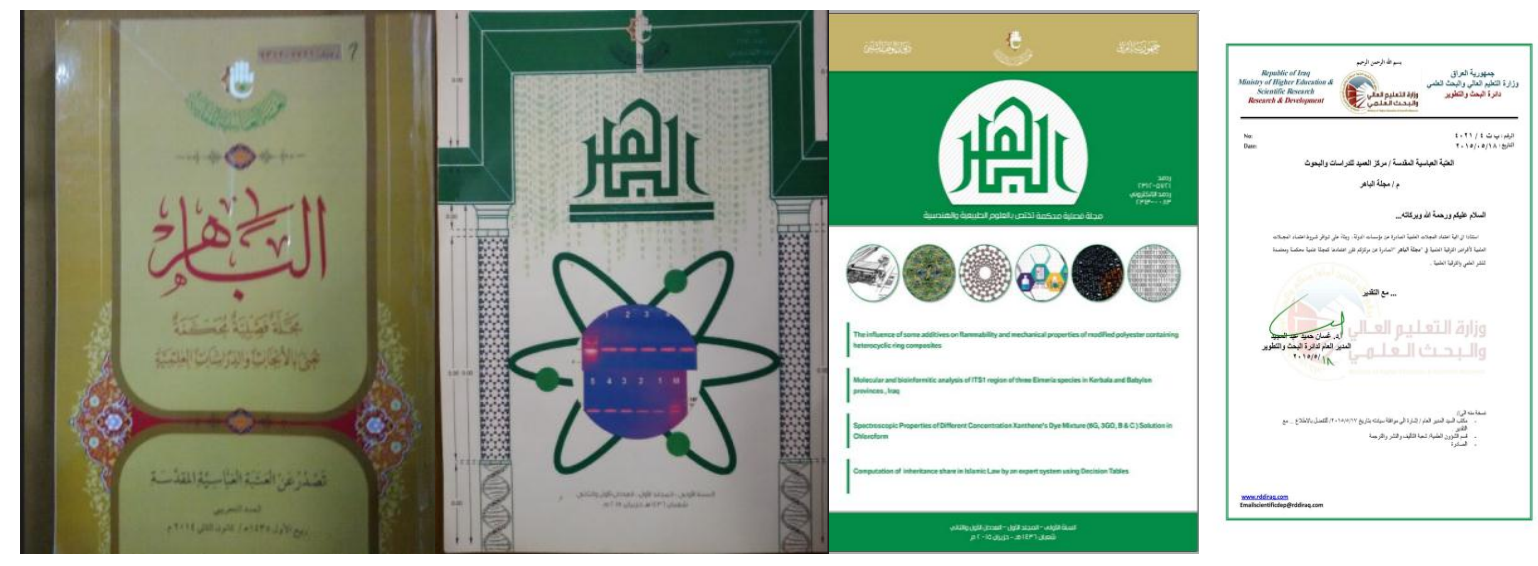


\section{\&- مجلة تراث الهلة:}

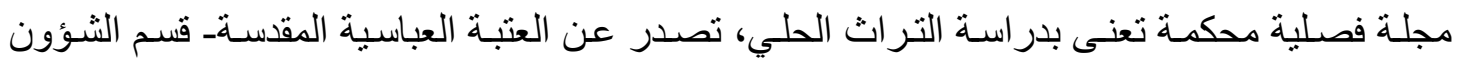
الفكريـة والمعـارف الإسـلامية والإنسـانية-مركز تراث الحلة، بإثـر اف السيد احمد الصـافي المتولي الثـرعي

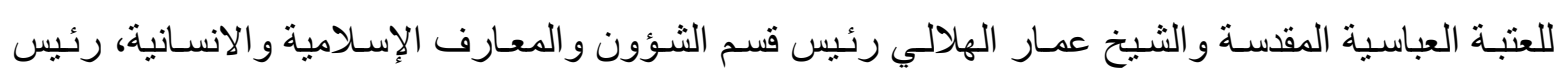

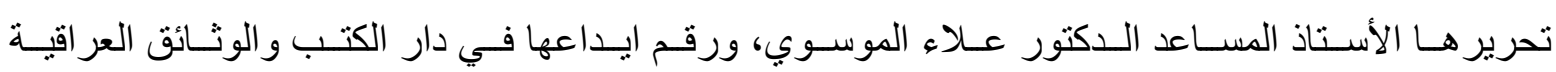

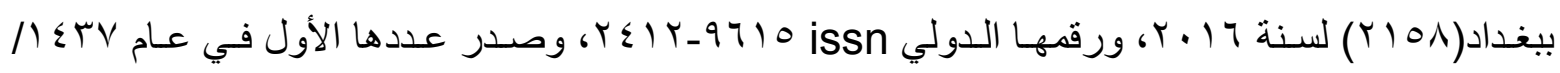
$\left({ }^{(\lambda 0)} r \cdot 17\right.$

\section{0- مجلة تصليم المحكمة:}

مجلة فصلية محكمـة، مختصـة بعلوم اللغة العربية وآدابها، تصدر عن مركز العميد الدولي للبحوث

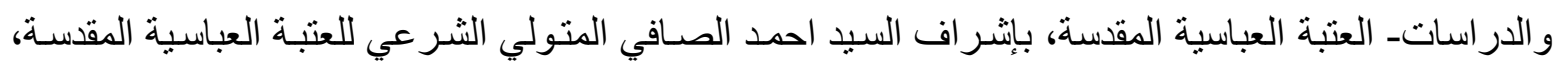
وير اس تحرير هـا الأستاذ الدكتور عبـاس رشيد الدده (جامعـة بابـلـ كليـة التربيـة)، ومدير تحريرهـا الأستاذ المساعد الدكتور مشتاق عباس معن(جامعة بغداد- كلية التربية ابن رشد) .

يهدف مركز العميد الدولي مـن إصـدار ها باعتبار هـا تمثنل (اللسـان هويـة) اذ تؤكد هيـاة التحريـر في

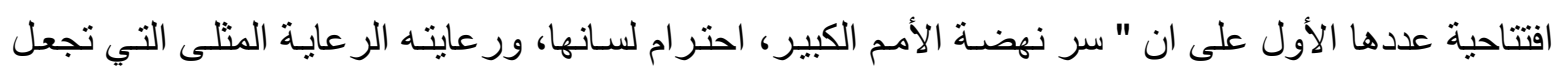

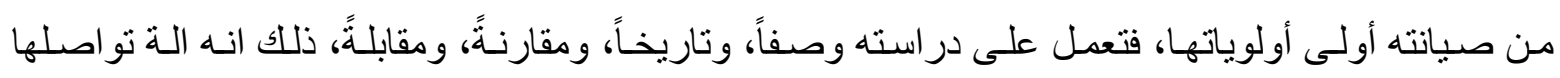

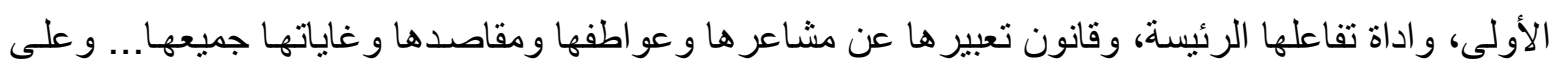
العكس من هذا النسق، نسق اخر تتمتع به الأمم التي لا يرقى مستوا اها الحضاري الى المستوى الذب يمكن انهان

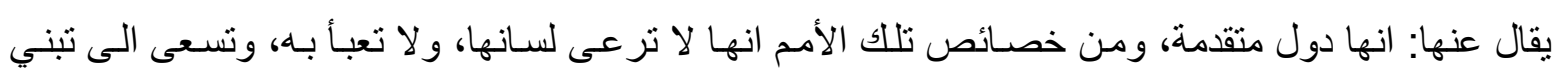

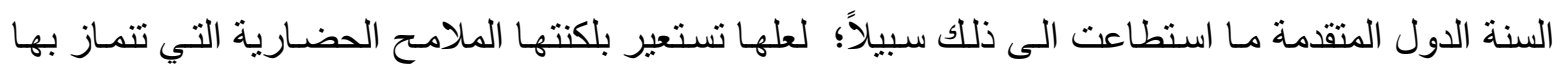

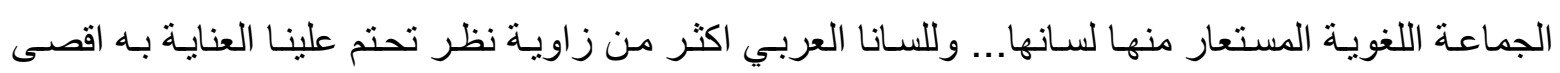
مديات العناية؛ لأنه علاوة على ما ذكرناه من أسباب، لسـان شريعتنا، ولسـان موطنتـا الاخروي(الجنـة)، فضـلاً عن انه منظار رؤيتنا الى امسنا المشرق".

وتأسيسـاً على القناعـات المسجلة في الاسطر السـابقة، ودعمـاً لأقـلام البـاحثين الاكـاديميين من أسـاتذة الجامعات المحلية و العربية والإقليمية والعالمية ممن يبحث في اللساني العربي، سواء اكتب بحرفه ام بـالحرف الإنكليزي، عمل مركز العميد الدولي للبحوث و الدراسـات على اصـدار مجلـة تعنى بأبحـاث اللغــة العربيـة و الدر اسـات المتخصصـة فيها؛ لتكون حاضـنة لنتاجـات البـاحثين الاكـاديميين الذين يرومـون تحكيم بحوثهم ودر اساتهم لأغر اض الترقية العلمية على وفق معايير وزارة التعليم العالي والبحث العلمي(آها. وتأتي هذه المجلة التي عمل المركز على إصدار ها والتي وسمها القائمون عليها بمجلة (تسليم) حلقة بحثية تحكيمية جديدة تضاف الى الحلقات البحثية التحكيميـة التي أسس لها المركز ، النسلاقاً من سياسـة العتبـة العباسية المقدة التي تعمل على رعاية النتاجات المعرفية والابداعية وتحث على تفعيلها في المجتمعين: العام 
و الاكـاديمي. و المجلـة مجـازة من وزارة التعليم العـالي والبحث العلمي العر اقيـة، ومعتمدة لأغر اض الترقيـة

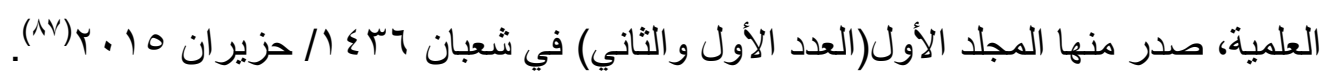

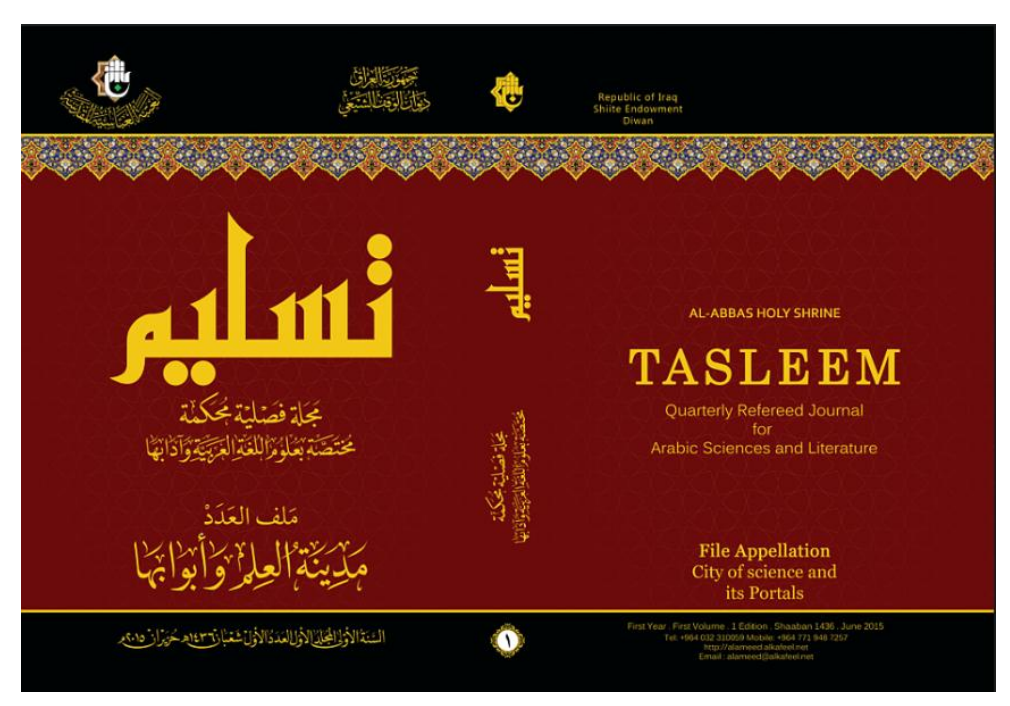

الغلاصة: توصل البحث الى نتائج عدة من أهمها:

ا - جاء دخول العتبات المقدة الى المعترك الاكـاديمي نقلة نوعية في عملية النشر الاكـاديمي، اذ كان يعتقد

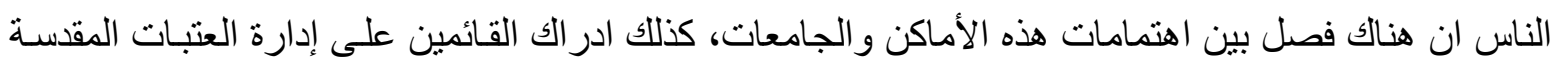

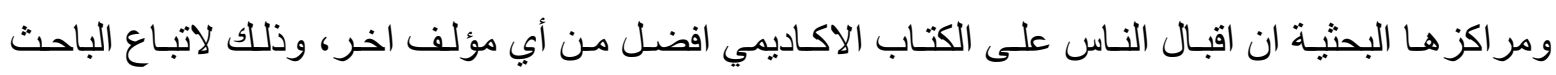

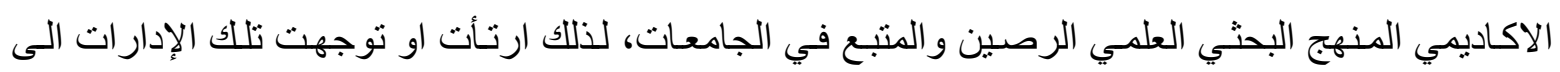

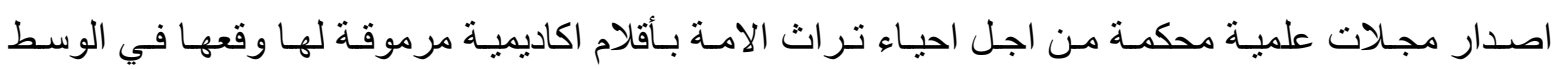

$$
\text { الاكاديمي او غير الاكاديمي. }
$$

r- ادت العتبـات المقدسة في كربلاء وادارتها ومن خـلال المجلات التي تصدر عنها سواء كانت مجلات المحكمة او غير المحكمة دوراً كبيرًا في دعم حركة النشر الاكاديمي في العراق، وذلك للخدمات الجليلة التي تقدمها تلك المجلات للباحثين ومنها النشر المجاني، والمكافات الماليـة المجزيـة التي تمنحها للباحثين الذين ينشرون ابحاثهم في مجلاتها، وبسبب الثقة المنبادلة بين الباحثين و المؤسسـات الناثـرة للنتاجـات العلميـة وذلك لوجود هياة استشارية وتحريرية مرموقة(خروجها من المحلية الى الإقليمية ومن ثم الى العالميـة اذ توجد في

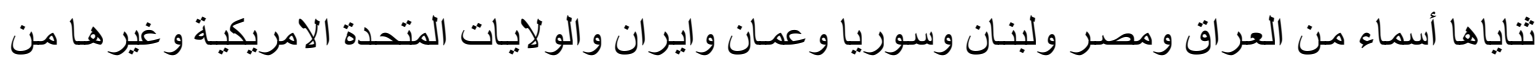

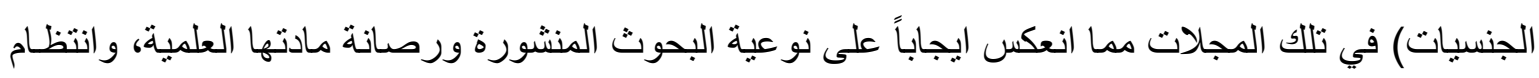
النشر فيها.

بـ وصـول مجـلات العتبـات المقدسـة الى ابعـد المديات المحليـة و الإقليميـة والعالميـة بسبب السمعة الطيبـة

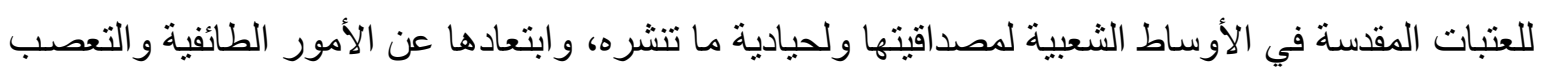
و التحزب، وبسبب إمكاناتها المادية والمعنوية ومر اكز هـا المنتشرة في ارجاء العالم، وتوزيع اغلب نتاجاتها

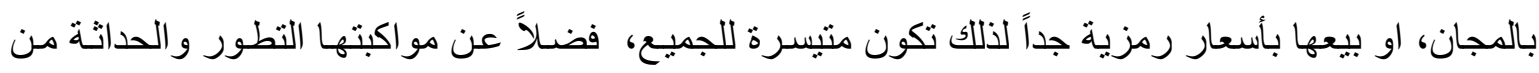


خلال طرح ما تنشره من نتاجات علمية على المواقع الاليكترونية(الانترنيت) مجانسا وبطرق حديثة وميسرة وسهلة.

ع - تنـوع موضـو عات مجـلات العتبـات المقدسـة وا هتماماتهـا واختصاصـاتها، اذ هـي تلائـم وتلامس جميع الاختصاصات الجامعية، فمنها ما يختص بالدر اسات والأبحاث الإنسانية وهنا تتفرع الى اللغة العربية وآدابها

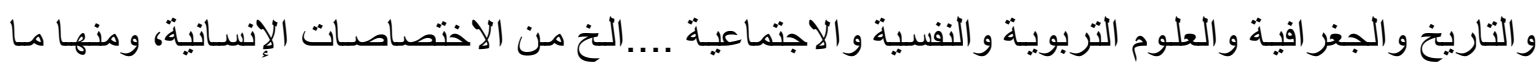
يختص بالدر اسـات والابحساث العلميـة كالطب و الهندسـة و العلوم الطبيعيـة...الخ مـن الاختصاصـات العلميـة الأخرى، وتتفرع ايضاً هذه الموضو عات الى عناوين اصغر لتشمل جميع مفاصل الحياة المختلفة فمنها مـا

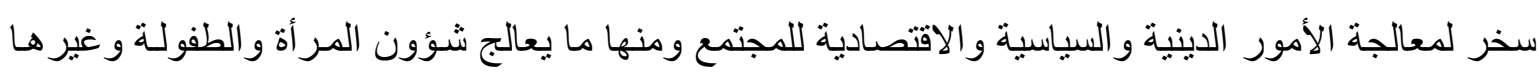

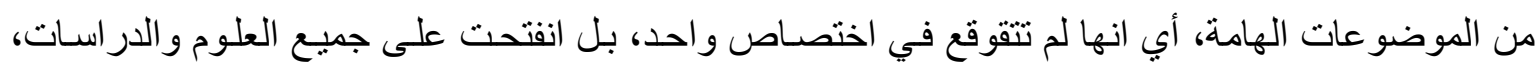
وبجميع اللغات.

هـ الأمسور الفنبـة المتوفرة في المجـلات العلميـة الصـادرة من العتبـات المقدسـة دون غيرهـا مـن المجـلات، و نقصد بهـا الإخر اج الفنـي الممتـاز ، كمـا ان مؤسسـات العتبـة دؤوبـة على اخر اج مجلاتها بأنتكال و الوان و احجام مناسبة جداً للباحث وللقارئ، اذ يستخدم في طباعتها ارقى أنواع الورق، و الطباعة الملونة الزاهيـة، لاسيما بعد افتتاح العتبة العباسية والحسينية المقدة مطبعتي الكفيل والوارث وبمو اصفات عالية و عالمية.

\section{الهوامش}

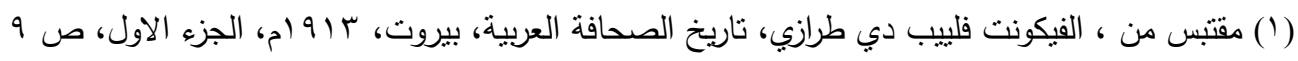

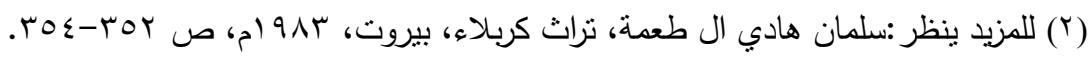

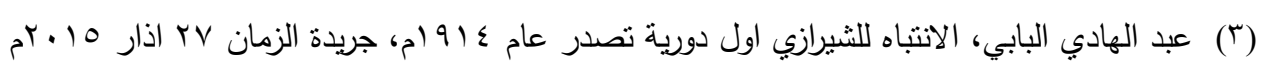

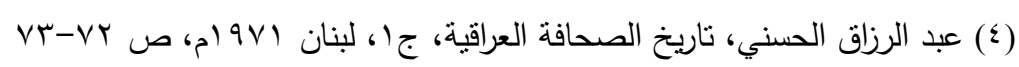

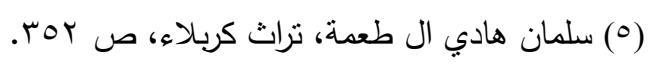

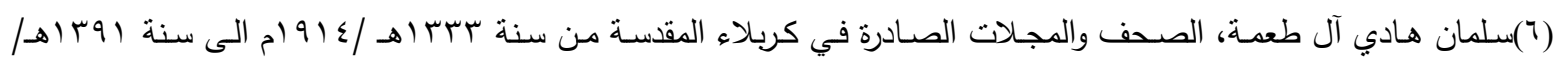

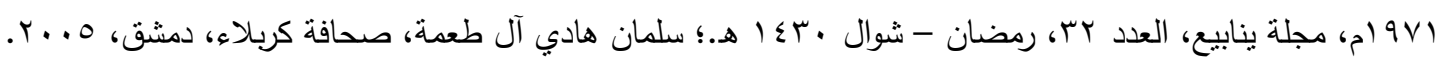

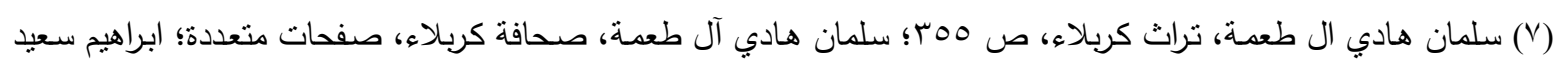

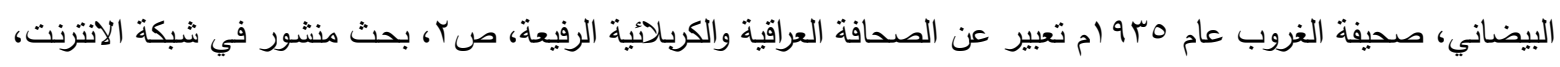

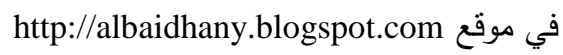

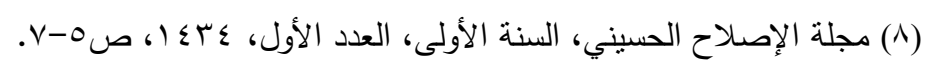

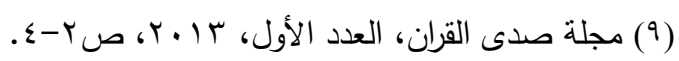

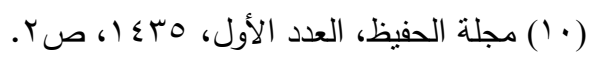

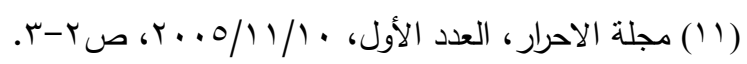

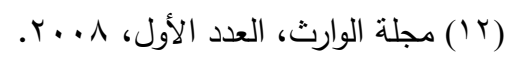

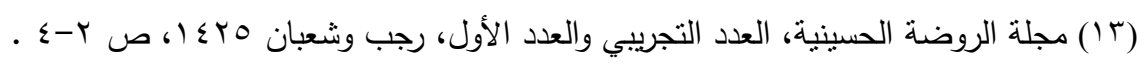

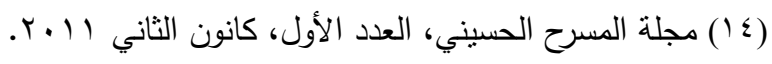

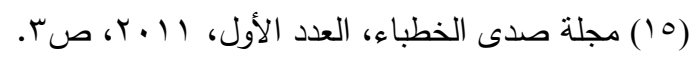

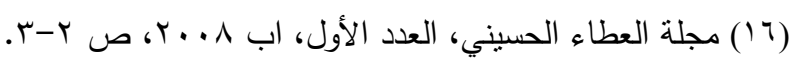




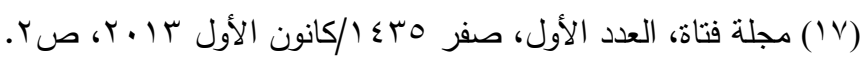

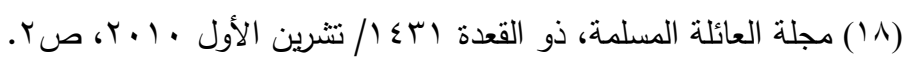

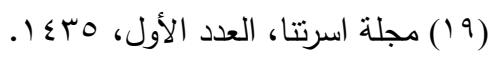

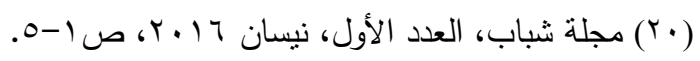

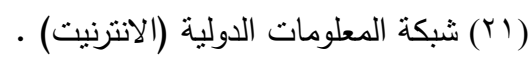

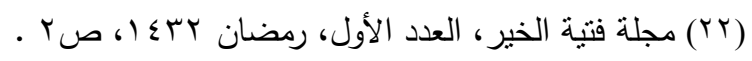

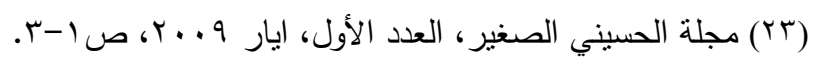

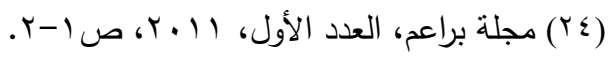

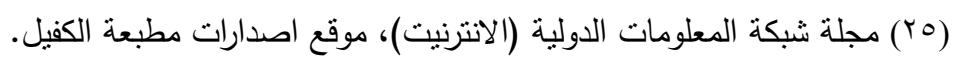

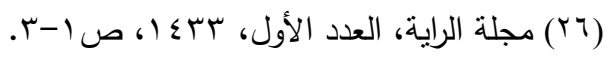

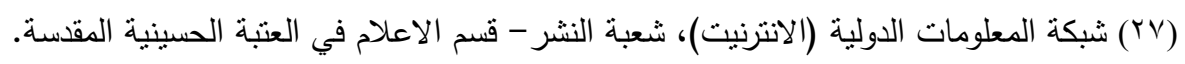

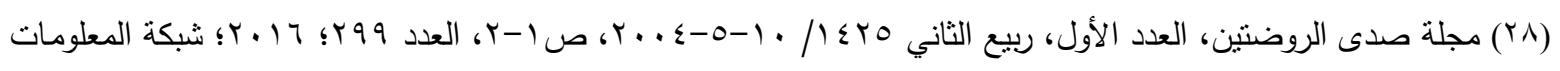

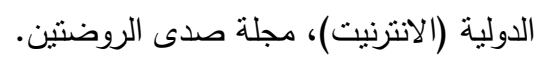

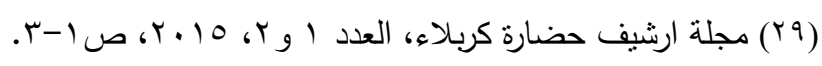

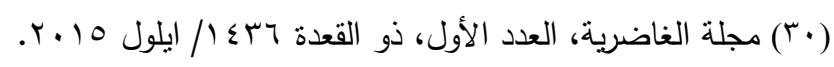

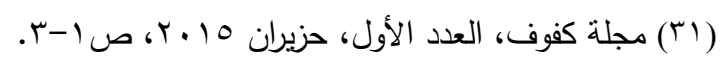

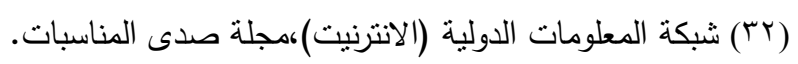

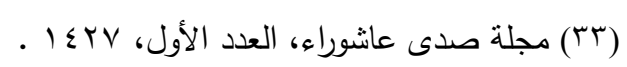
( (

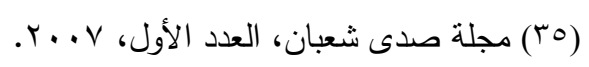

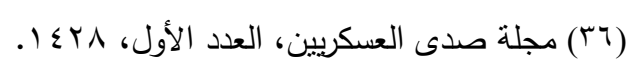

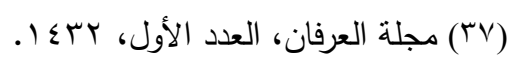

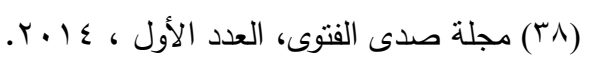

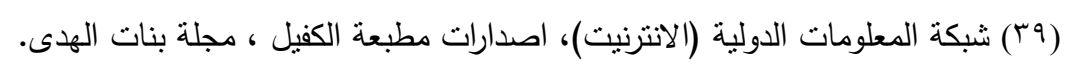

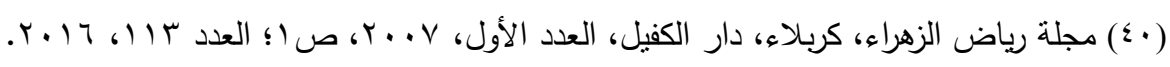

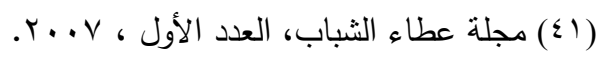
(r\&) شبكة المعلومات الدولية (الانترنيت)، اصدارات مطبعة الكفيل، سلسلة المناهل العقائدية للثباب. ( (ז) شبكة المعلومات الدولية (الانترنيت)، اصدارات مطبعة الكفيل، سلسلة المناهل الاخلاقية للثباب.

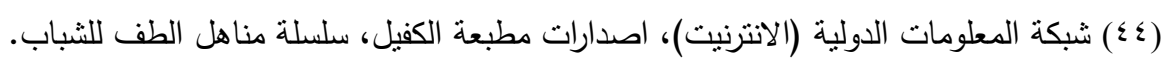

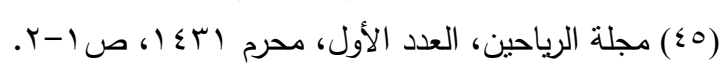

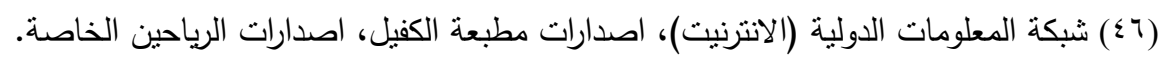

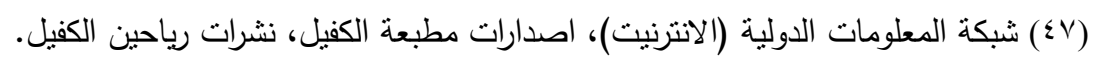

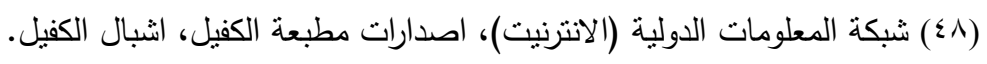

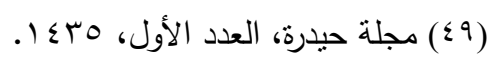

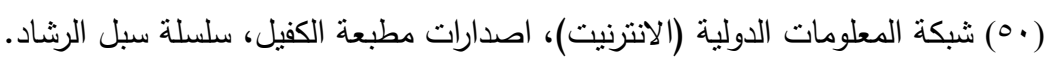

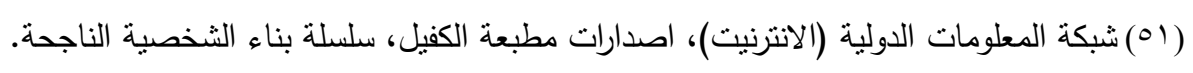

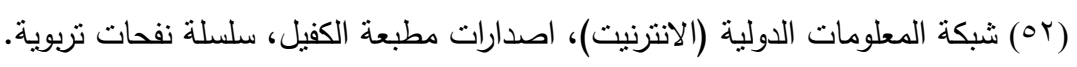

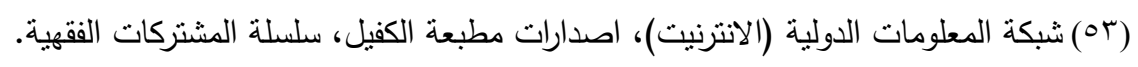


(ـ) شبكة المعلومات الدولية (الانترنيت)، اصدارات مطبعة الكفيل، سلسلة قراءات انطباعية في نهج البلاغة. (00) شبكة المعلومات الدولية (الانترنيت)، اصدارات مطبعة الكفيل، نشرة الكفيل .

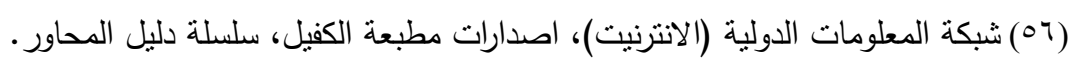
(ov) شبكة المعلومات الدولية (الانترنيت)، اصدارات مطبعة الكفيل، سلسلة منشورات المكتبة.

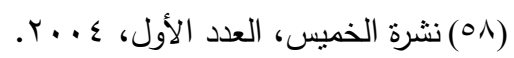

(هو) شبكة المعلومات الدولية (الانترنيت)، اصدارات مطبعة الكفيل، سلسلة نشرة اذاعة الكفيل.

( • (7) شبكة المعلومات الدولية (الانترنيت)، اصدارات مطبعة الكفيل، سلسلة نشرة الكفيل. ( • (7) شبكة المعلومات الدولية (الانترنيت)، اصدارات مطبعة الكفيل، سلسلة نشرات مركز الدراسات الاستراتيجية.

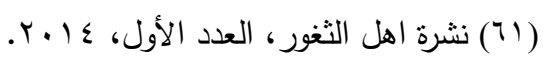

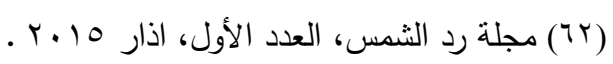

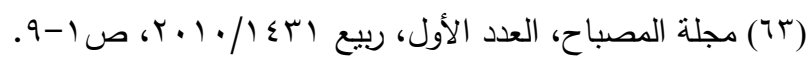

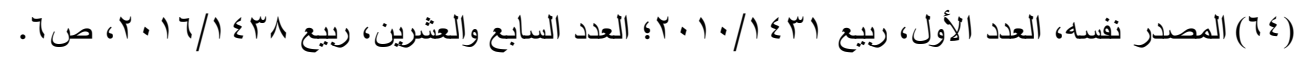

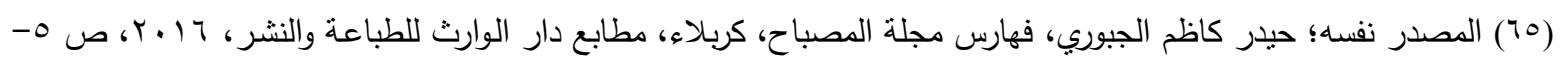

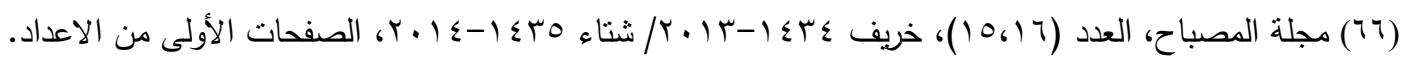

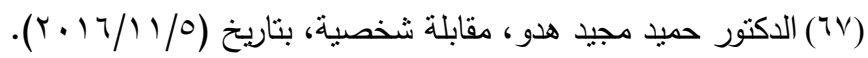

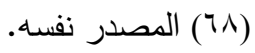

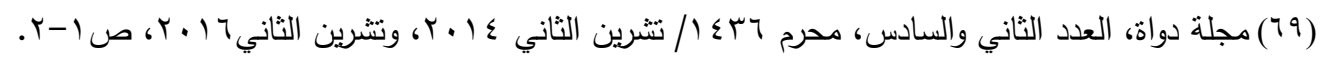

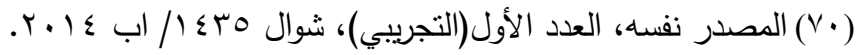

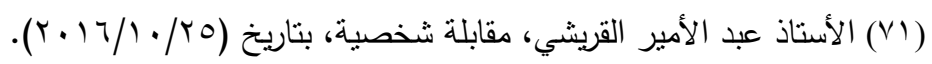

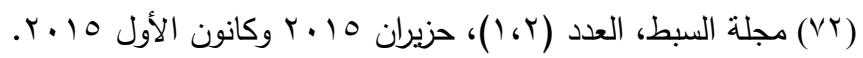

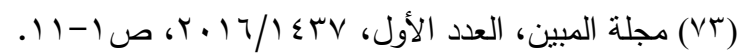
(V乏)

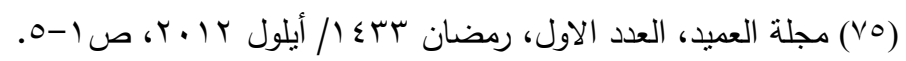
(VT)

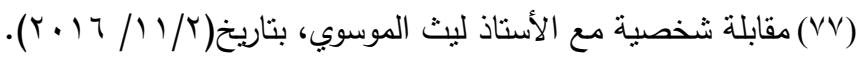

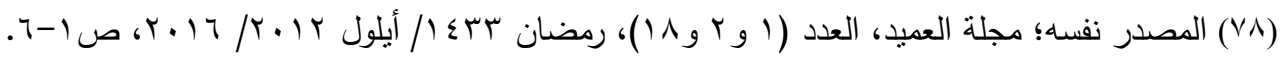

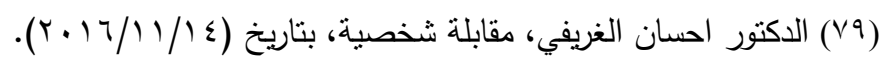

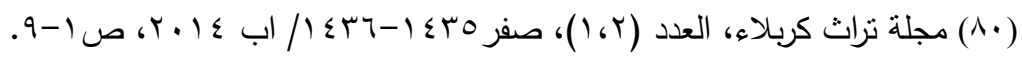

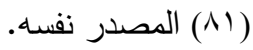

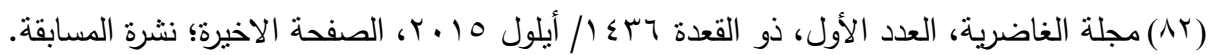

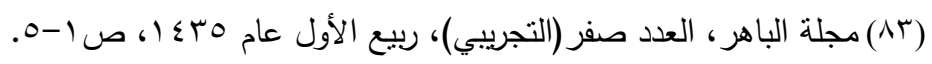

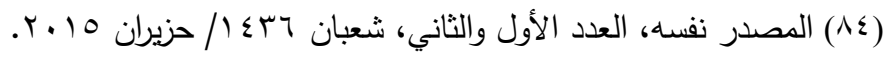

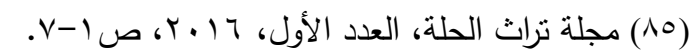

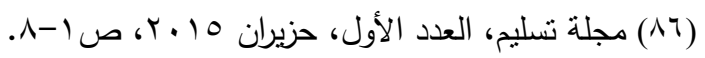
(Av) 